\title{
Umbilical Cord as Prospective Source for Mesenchymal Stem Cell-Based Therapy
}

\author{
Irina Arutyunyan, ${ }^{1}$ Andrey Elchaninov, ${ }^{2}$ Andrey Makarov, ${ }^{1}$ and Timur Fatkhudinov ${ }^{1,2}$ \\ ${ }^{1}$ Research Center for Obstetrics, Gynecology and Perinatology, Ministry of Healthcare of the Russian Federation, \\ No. 4, Oparin Street, Moscow 117997, Russia \\ ${ }^{2}$ Pirogov Russian National Research Medical University, Ministry of Healthcare of the Russian Federation, \\ No. 1, Ostrovitianov Street, Moscow 117997, Russia \\ Correspondence should be addressed to Timur Fatkhudinov; tfat@yandex.ru
}

Received 27 April 2016; Accepted 14 July 2016

Academic Editor: Salvatore Scacco

Copyright (C) 2016 Irina Arutyunyan et al. This is an open access article distributed under the Creative Commons Attribution License, which permits unrestricted use, distribution, and reproduction in any medium, provided the original work is properly cited.

\begin{abstract}
The paper presents current evidence on the properties of human umbilical cord-derived mesenchymal stem cells, including origin, proliferative potential, plasticity, stability of karyotype and phenotype, transcriptome, secretome, and immunomodulatory activity. A review of preclinical studies and clinical trials using this cell type is performed. Prospects for the use of mesenchymal stem cells, derived from the umbilical cord, in cell transplantation are associated with the need for specialized biobanking and transplant standardization criteria.
\end{abstract}

\section{Introduction}

Many researchers consider the transplantation of mesenchymal stem cells (MSCs) to be the most effective tool for cell therapy, due to the simultaneous activation of multiple mechanisms (paracrine, trophic, immunomodulatory, and differentiation), affecting all stages of the regeneration of damaged tissues. Bone marrow-derived MSCs (BM-MSCs) are the most extensively characterized as they are the historically accepted "gold standard" of MSCs. Nevertheless, currently there is active research work regarding MSCs from other sources-adipose tissue, peripheral and umbilical cord blood, amniotic fluid, skin, dental pulp, synovium, umbilical cord tissue, placental complex, endometrium, and others. In fact, evidence has suggested that MSCs may be present virtually in any vascularized tissue throughout the whole body [1]. All these cell types meet the minimum criteria for MSCs but have significant differences in their features. Our review focuses on umbilical cord-derived MSCs (UC-MSCs), cells that have a unique combination of prenatal and postnatal stem cell properties.

\section{The Origin and Morphology of the Human Umbilical Cord}

The umbilical cord develops from the yolk sac and allantois and becomes a conduit between the developing embryo or fetus and the placenta. The umbilical cord stroma contains gelatinous substance called Wharton's jelly after Thomas Wharton (1614-1673), an English physician and anatomist. Wharton's jelly protects the blood vessels (two umbilical arteries and one umbilical vein) from clumping and provides cord flexibility. This substance is made largely from glycosaminoglycans, especially hyaluronic acid and chondroitin sulfate. Collagen fibers are the main fibrillary component, while elastic fibers are absent. The cell component is presented by mesenchyme-derived cells (fibroblasts, myofibroblasts, smooth muscle cells, and mesenchymal stem cells) [2] In contrast to most tissues of the body, there are no capillaries in Wharton's jelly: there is an active process of hematopoiesis and capillaries formation in umbilical cord stroma at week 6 of development; however, at 7-9 weeks, hematopoiesis stops and capillaries regress [3]. Cross-section of the human umbilical cord is shown in Figure 1. 

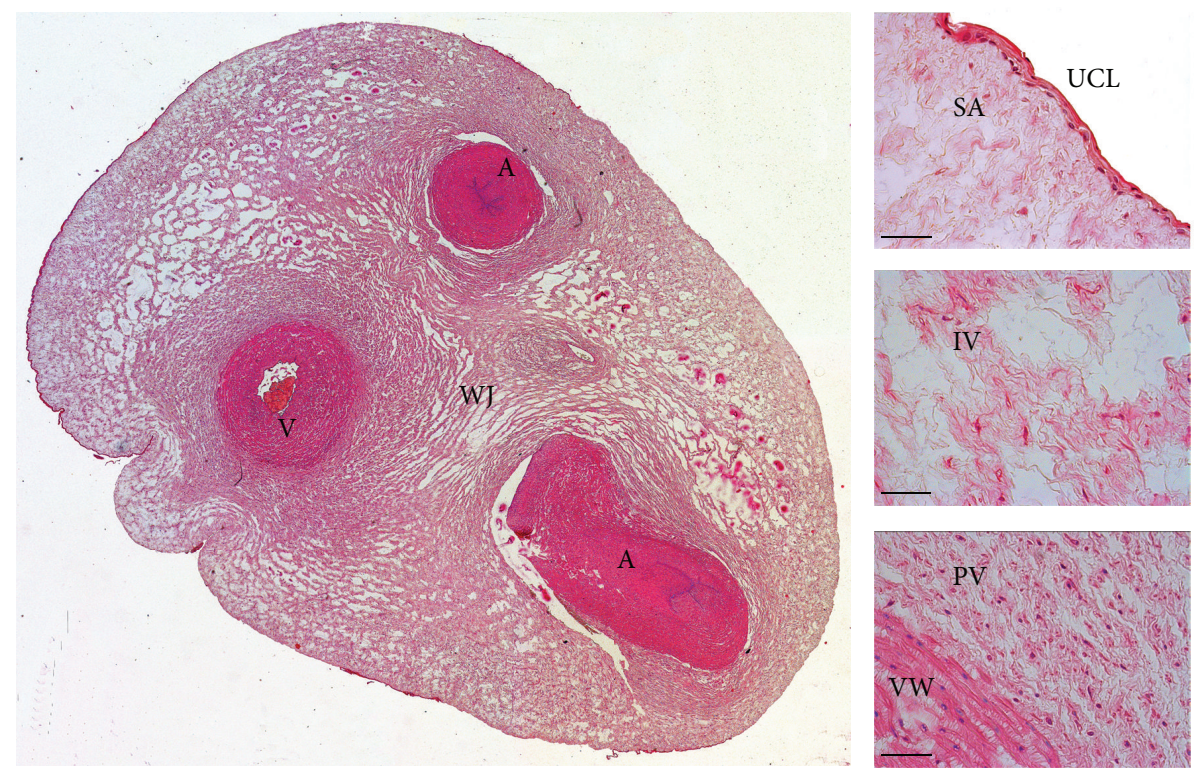

FIgURE 1: Cross-section of the human umbilical cord. A: artery; V: vein; WJ: Wharton's jelly; UCL: umbilical cord lining; SA, IV, and PV: subamnion, intervascular, and perivascular zones of Wharton's jelly; VW: blood vessel wall. Hematoxylin and eosin staining, scale bar = $200 \mu \mathrm{m}$.

\section{The Umbilical Cord as a Source of Mesenchymal Stem Cells}

In 1974, umbilical cord blood was declared to be the source of hematopoietic stem and progenitor cells [4], and the remaining umbilical cord tissue was considered medical waste with no scientific value. This point of view was completely revised in 1991, when McElreavey et al. isolated fibroblast-like cells from Wharton's jelly and characterized them [5]. In 2004, these fibroblast-like cells were proved to be MSCs as they expressed CD29, CD44, CD51, CD73, and CD105, lacked expression of CD34 and CD45, and were able to differentiate into cells of the adipogenic and osteogenic lineages [6]. Currently, the umbilical cord MSCs include cells derived from the total umbilical cord or its different sections (perivascular, intervascular, and subamnion zones of Wharton's jelly and subendothelial layer but not from umbilical cord lining or inner blood vessel walls) [2].

Figure 2 shows the characteristics of cultured cells derived from Wharton's jelly according to the minimal criteria to define human MSCs as proposed by the Mesenchymal and Tissue Stem Cell Committee of the International Society for Cellular Therapy (ISCT): (1) MSCs must be plastic-adherent when maintained in standard culture conditions; (2) MSCs must express CD105, CD73, and CD90 and lack expression of CD45, CD34, CD14 or CD11b, CD79a or CD19, and HLADR surface molecules; (3) MSCs must differentiate into osteoblasts, adipocytes, and chondroblasts in vitro [40].

\section{The Origin of Wharton's Jelly MSCs}

In 2008, Wang et al. presumed that early in embryogenesis, hematopoietic cells and MSCs migrate from the yolk sac and aorta-gonad-mesonephros to the placenta and then back to the fetal liver and bone marrow through the umbilical cord. During these two migration waves, some cells are trapped in Wharton's jelly and are retained therein throughout the whole period of gestation. The new microenvironment changes the properties of migrating cells, which probably explains their differences from BM-MSCs [41].

\section{Isolation of Primary Cell Culture from Wharton's Jelly}

Most protocols for primary cell culture isolation from Wharton's jelly consist of three steps:

(1) Removal of the epithelial, vascular, and perivascular tissues.

(2) Mechanical grinding and enzymatic digestion using trypsin, collagenases I, II, or IV, dispase, protease, and hyaluronidase.

(3) Transfer into the culture medium (standard culture media with human or fetal calf serum which may be supplemented with growth factors FGFb, EGF, PDGF, and VEGF) $[2,7,42]$.

In addition, an explant culture method can be applied; it avoids the damaging effects of enzymes on cells and reduces the processing time of the biomaterial ("plate and wait" procedure) [43]. The common explant method of isolating UC-MSCs involves mincing the umbilical cords into small fragments, which are then attached to a culture dish bottom from which the cells migrate. One of the disadvantages of this method is that the fragments frequently float up from the bottom of the dish, thereby reducing the cell recovery rate. In some protocols, a stainless steel mesh is used to protect the tissue from floating [44]. 

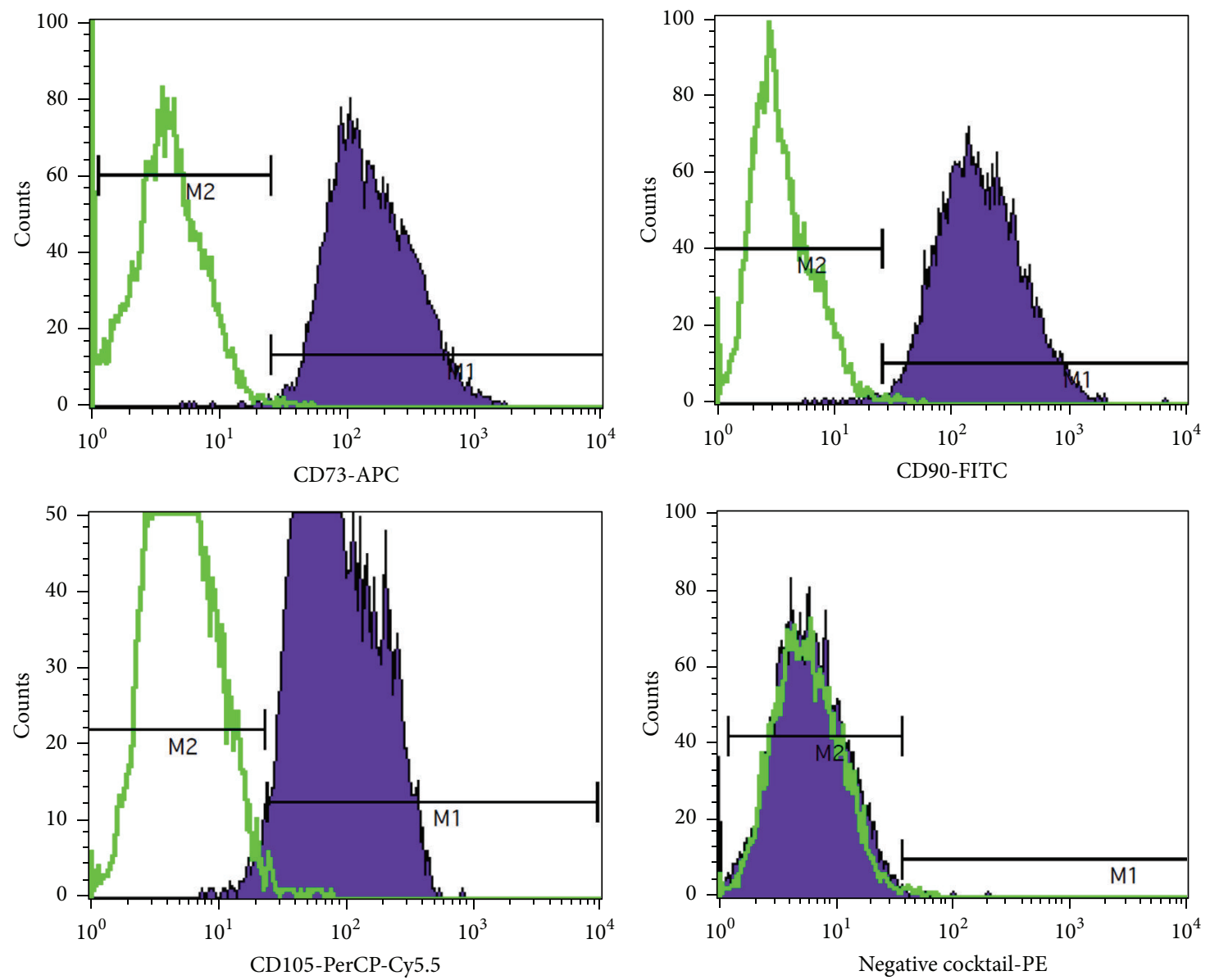

(a)

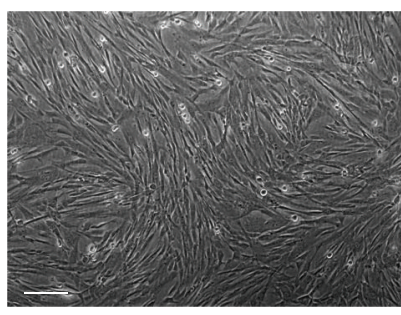

(b)

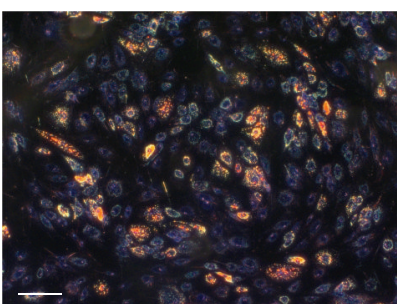

(c)

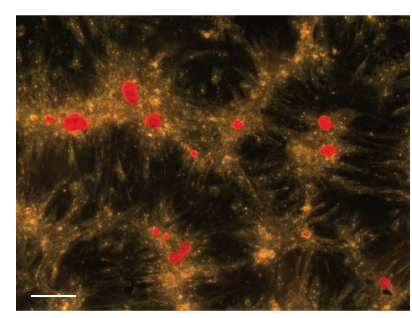

(d)

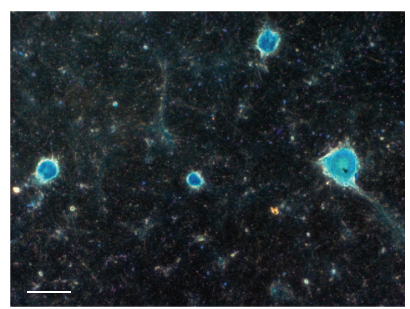

(e)

FIGURE 2: The characteristics of cultured cells derived from Wharton's jelly according to minimal criteria to define human MSCs proposed by ISCT. (a) Analysis of immunophenotype with BD Stemflow ${ }^{\mathrm{TM}}$ hMSC Analysis Kit (BD Biosciences). Negative MSC cocktail includes PE CD45, PE CD34, PE CD11b, PE CD19, and PE HLA-DR antibody conjugates. (b) Phase contrast capture of UC-MSCs at the fourth passage. Scale bar: $200 \mu \mathrm{m}$. (c) Adipogenic differentiation with StemPro ${ }^{\circledR}$ Adipogenesis Differentiation Kit (Gibco). Lipid droplets are stained with Sudan III. Scale bar: $200 \mu \mathrm{m}$. (d) Osteogenic differentiation with StemPro Osteogenesis Differentiation Kit (Gibco). Calcificated nodules are stained with Alizarin red S ( $\mathrm{pH}=4.1)$. Scale bar: $200 \mu \mathrm{m}$. (e) Chondrogenic differentiation with StemPro Chondrogenesis Differentiation Kit (Gibco). Mucopolysaccharides are stained with Alcian blue $(\mathrm{pH}=2.5)$. Scale bar: $200 \mu \mathrm{m}$.

According to some reports, the explant method allows the selection of a cell fraction with higher proliferative potential $[45,46]$, but a remarkable variation of cell phenotype expressions was distinguished compared to enzymatic digestion [47, 48]. In a recent study, three explant culture methods and three enzymatic methods were compared. MSC isolation using the $10 \mathrm{~mm}$ size tissue explant method led to shorter primary culture time, higher numbers of isolated cells, and higher proliferation rates compared with other isolation methods. Immune phenotype and multilineage differentiation capacity did not differ significantly among six groups [49]. It was also found that UC-MSCs isolated by explant technique always reached proliferation arrest earlier, irrespective of initial population doubling times, but the mechanism explaining this effect is still unclear [50]. On the contrary, later studies showed that cells obtained from explants presented similar 
characteristics (morphology, population doubling time, postthaw survival, differentiation capacity, and phenotype) to those from enzymatic protocols [51].

According to published data $[52,53]$ and our own laboratory data, the efficacy of isolation of primary cell culture from Wharton's jelly amounts to $100 \%$. In comparison, the efficacy of MSC isolation from umbilical cord blood does not exceed $60 \%$; amniotic fluid is $90 \%$; placenta varies from $62.5 \%$ to $100 \%[52,53]$. Wharton's jelly tissue yields the highest concentration of allogeneic mesenchymal stem cells: yields for bone marrow ranged from 1 to 317,400 cells/mL; yields for adipose tissue ranged from 4,737 to $1,550,000$ cells $/ \mathrm{mL}$ of tissue; and yields for umbilical cord tissue ranged from 10,000 to $4,700,000$ cells/cm of umbilical cord [54].

It should be particularly noted that almost all culture laboratories use umbilical cords obtained after Caesarean sections, because vaginal delivery significantly increases the risk of contamination of primary biological material. Some researchers suppose that viable MSCs can only be isolated from fresh umbilical cord tissue, not from frozen tissue fragments [55]. According to another report, MSCs derived from frozen cord tissue exhibited decreased plating efficiency and increased doubling times but near equivalent maximum cell expansion compared with fresh cord tissue [56].

\section{The Proliferative Potential and the Karyotype Stability of UC-MSCs}

UC-MSCs have higher proliferative potential than BM-MSCs (the "gold standard" for MSCs comparison) or MSCs from other postnatal (adipose tissue) and neonatal sources (placenta and amniotic membrane) $[13,16,17,57,58]$. The mean of CFU-F (colony-forming unit-fibroblast) colonies per $1 \times$ $10^{6}$ nucleated cells was significantly higher in UC-MSCs $(800$, range 300-2000) than in BM-MSCs (36, range 16-64) as determined by the CFU-F assay based on Castro-Malaspina's method [57]. CFU-F frequency determined by limiting dilution assay also confirmed a higher frequency of CFU-F in UC-MSCs $(1: 1609 \pm 0.18)$ than in BM-MSCs $(1: 35700 \pm 0.01)$ [57]. According to another report, typical CFU-F efficiency (the ratio of number of cells forming colonies under clonal conditions and number of cells seeded directly after isolation) for BM-MSCs ranged from $0.001 \%$ to $0.01 \%$, while for UCMSCs it reached $0.2-1.8 \%$ [59].

It has been reported that cell doubling time for UC-MSCs approximates $21 \mathrm{~h}$ [58], $24 \mathrm{~h} \mathrm{[57],} 40 \mathrm{~h}[13,46]$, and $45 \mathrm{~h}[56]$. Importantly, according to recent data, each individual UCMSCs sample exhibited different population doubling rates and reached senescence at different passages due to unique genetic and epigenetic profiles, irrespective of isolation protocol [50]. A sufficient amount of the starting biomaterial (umbilical cord weight is nearly $40 \mathrm{~g}$ ) and high telomerase activity of UC-MSCs permit obtaining $10^{9}$ cells from one cord while maintaining their normal karyotype for 6 passages [60, 61]. Since passage 7, the telomerase activity of UC-MSCs is significantly reduced; but cell karyotype is stable for at least 25 passages $[22,62]$.
TABLE 1: The expression of cell surface markers on UC-MSCs (according to [2, 7-9]).

\begin{tabular}{lcccc}
\hline \multicolumn{2}{c}{ Positive markers } & Contradictory data & \multicolumn{2}{c}{ Negative markers } \\
\hline CD10 & CD58 & CD54 & CD3 & CD49a \\
CD13 & CD59 & CD105 & CD11b & CD50 \\
CD29 & CD61 & CD106 & CD14 & CD53 \\
CD44 & CD73 & CD117 & CD19 & CD56 \\
CD49b & CD90 & CD144 & CD31 & CD71 \\
CD49c & CD106 & CD146 & CD33 & CD80 \\
CD49d & CD166 & & CD34 & CD86 \\
CD49e & CD325 & & CD38 & CD133 \\
CD51 & HLA-I & & CD40 & CD140 $\alpha$ \\
CD56 & & & CD45 & HLA-II \\
\hline
\end{tabular}

TABLE 2: The expression of pluripotency markers on UC-MSCs (according to $[2,7-11])$.

\begin{tabular}{lc}
\hline Positive markers & Contradictory data \\
\hline REX2 & STRO-1 \\
GD2 & OCT4 \\
SOX2 & SSEA-4 \\
NANOG & \\
Tra-1-60 & \\
Tra-1-81 & \\
SSEA-1 & \\
DNMT3B & \\
GABRB3 & \\
\hline
\end{tabular}

\section{UC-MSCs Phenotype}

To date, the expression profile of surface markers and pluripotency markers of UC-MSCs has been investigated extensively (Tables 1 and 2).

Particular attention is drawn to CD105 (endoglin, a part of the TGF beta receptor complex). According to ISCT decision, CD105 is a required marker for MSCs verification [40]; however, different data contradict each other. In most studies, it has been shown that CD105 presents on UC-MSCs surface [2, 7-9], and its expression is maintained during long-term cultivation (at least 16 passages) [63]. However, a few studies have demonstrated that UC-MSCs do not express CD105 at all [64] or until passage 5 [65]. Reduction in mesenchymalmarker (CD73, CD90, and CD105) expression on UC-MSCs may occur under ischemic conditions influenced mainly by hypoxia [66]. In accordance with our laboratory data, more than $98 \%$ of the UC-MSCs express CD105 on passages 2-5 as measured by flow cytometry (Figure 2).

Data about the expression of pluripotent specific markers on UC-MSCs are contradictory. In different reports, the expression of these markers was shown only under certain conditions: solely on early passages [67], or when grown in the presence of human embryonic stem cells medium on mouse feeder cells [10], or after lowering $\mathrm{O}_{2}$ concentration from $21 \%$ to $5 \%$ level [68], or after the selection of CD105+ cells and their subsequent cultivation under suspension culture condition [69]. Flow cytometric analysis revealed 
TABLE 3: The genes expressed at higher levels in UC-MSCs compared to MSCs derived from adipose tissue, bone marrow, and skin (according to $[12])$.

\begin{tabular}{|c|c|c|c|c|}
\hline \multirow{2}{*}{ Genes } & \multirow{2}{*}{ Functions } & \multicolumn{3}{|c|}{ Expression levels in UC-MSCs compared to } \\
\hline & & BM-MSC & AT-MSC & Skin-MSC \\
\hline $\begin{array}{l}\text { HAND1 } \\
\text { Heart and neural crest derivatives } \\
\text { expressed } 1\end{array}$ & Plays a critical role in heart development & Higher* & Higher & Higher \\
\hline $\begin{array}{l}\text { AFP } \\
\text { Alpha-fetoprotein }\end{array}$ & $\begin{array}{l}\text { The major plasma protein produced in the liver during } \\
\text { fetal life }\end{array}$ & Higher & Higher & Higher \\
\hline $\begin{array}{l}\text { DKK1 } \\
\text { Dickkopf homolog } 1 \\
\end{array}$ & $\begin{array}{l}\text { An inhibitor of the WNT-signaling pathway critical for } \\
\text { endodermal development }\end{array}$ & Higher & ns & Higher \\
\hline $\begin{array}{l}\text { DSG2 } \\
\text { Desmoglein } 2 \\
\end{array}$ & $\begin{array}{l}\text { An important component of desmosomes in epithelial } \\
\text { cell type }\end{array}$ & Higher & ns & Higher \\
\hline $\begin{array}{l}\text { KRT8,19 } \\
\text { Keratin } 8,19\end{array}$ & $\begin{array}{l}\text { The major intermediate filament proteins of epithelial } \\
\text { cells }\end{array}$ & Higher & Higher & Higher \\
\hline $\begin{array}{l}\text { KRT18 } \\
\text { Keratin } 18\end{array}$ & $\begin{array}{l}\text { The major intermediate filament proteins of epithelial } \\
\text { cells }\end{array}$ & Higher & ns & Higher \\
\hline
\end{tabular}

${ }^{*}$ Significantly increased mRNA expression between mutually compared stem cell types (fold change $>2 ; P$ value $<0.05$ ). ns: not significant.

that neural ganglioside GD2(+)-sorted UC-MSCs showed increased expression of SSEA-4, OCT4, SOX2, and NANOG in comparison to unsorted or GD2-negative cells [70].

\section{Transcriptomic Profile of UC-MSCs}

In 2012, De Kock et al. studied the global gene expression profiles of four human mesoderm-derived stem cell populations. Human UC-MSCs showed significant enrichment in functional gene classes involved in liver and cardiovascular system development and function compared to MSCs derived from adipose tissue, bone marrow, and skin [12]. The most significant differences were found for genes presented in Table 3.

In 2010, Hsieh et al. published interesting data comparing the gene expression profiles of BM-MSCs and UC-MSCs. It was found that, for the two MSC types, there were no common genes among the top 50 known genes most strongly expressed! Top 10 for UC-MSCs included genes encoding somatostatin receptor 1 , member 4 of immunoglobulin superfamily, gamma 2 smooth muscle actin, reticulon 1, natriuretic peptide precursor $\mathrm{B}$, keratin 8 , desmoglein 2 , oxytocin receptor, desmocollin 3 , and myocardin. The study also showed that genes related to cell proliferation $(E G F)$, PI3K-NFkB signaling pathway (TEK), and neurogenesis (RTN1, NPPB, and $N R P 2$ ) were upregulated in UC-MSCs compared to in BMMSCs [71].

The UC-MSCs and BM-MSCs were also screened for their surface expression of HLA antigens, costimulatory factors, and immune tolerance molecules $[9,13]$. It was found that the expression of MHCII molecules (HLA-DMA, -DRA, and -DPB1) in the BM-MSCs was 16-fold, 36-fold, and 4fold higher, respectively, compared with the UC-MSCs. The expression levels of immune-related genes TLR4, TLR3, JAG1, $\mathrm{NOTCH} 2$, and NOTCH3 in the BM-MSCs were 38-fold, 4fold, 5-fold, 3-fold, and 4-fold higher, respectively, compared with the UC-MSCs [13]. These results promise successful future use of allogeneic UC-MSCs for clinical trials.
A more detailed comparative analysis of the UC-MSCs transcriptome is presented in the review by El Omar et al. [9].

\section{The Multilineage Differentiation Potential of UC-MSCs}

In vitro UC-MSCs showed very high differentiation capacity: these cells were able to differentiate into chondrocytes, adipocytes, osteoblasts, odontoblast-like cells, dermal fibroblasts, smooth muscle cells, skeletal muscle cells, cardiomyocytes, hepatocyte-like cells, insulin-producing cells, glucagon-producing cells, and somatostatin-producing cells, sweat gland cells, endothelial cells, neuroglia cells (oligodendrocytes), and dopaminergic neurons [ $8,15,21,42,72-75]$. In 2014, it was found that under specific conditions UC-MSCs expressed markers of male germ-like cells and primordiallike germ cells; such a possibility had previously been shown only for embryonic stem cells (ESCs) or induced pluripotent stem cells $[76,77]$.

Comparison of the differentiation potential of UC-MSCs and MSCs from other sources (bone marrow and adipose tissue) is the subject of numerous studies presented in Table 4 .

A number of studies have demonstrated the possibility of UC-MSCs' differentiation after genetic modification (transduction or transfection). UC-MSCs overexpressing hepatocyte growth factor (HGF) could differentiate into dopaminergic neuron-like cells secreting dopamine, tyrosine hydroxylase, and dopamine transporter [78] and promoted nerve fiber remyelination and axonal regeneration one week after transplantation in rats with collagenase-induced intracerebral hemorrhage [30]. After infection with adenovirus containing SF-1 cDNA, UC-MSCs had significantly higher expression of all steroidogenic mRNAs (including P450 sidechain cleavage enzyme, $3 \beta$-HSD, $17 \beta$-HSD type 3 , LH-R, ACTH-R, P450c21, and CYP17), secreted significantly more steroidogenic hormones (including testosterone and cortisol), and had significantly higher cell viability than differentiated BM-MSCs [79]. 
TABLE 4: Comparison of the differentiation potential of UC-MSCs and MSCs from other sources.

\begin{tabular}{|c|c|c|c|c|c|}
\hline Induction & Parameter & UC-MSCs & BM-MSCs & AT-MSCs & Reference \\
\hline Osteogenic (35 days) & $\begin{array}{l}\text { The average number of bone nodules } \\
\text { from one well }\end{array}$ & $19 \pm 1.8$ & $7.5 \pm 1.3$ & $11 \pm 1.7$ & {$[13]$} \\
\hline Adipogenic (21 days) & $\begin{array}{l}\text { The ratio of differentiated adipocytes } \\
\text { from the total cells }\end{array}$ & $45 \pm 1.5 \%$ & $39 \pm 1 \%$ & $52 \pm 3.2 \%$ & {$[13]$} \\
\hline \multirow{5}{*}{ Neuronal (20 days) } & The number of primary neurospheres & $118 \pm 5.2$ & $80.4 \pm 3.4$ & $26 \pm 3.12$ & \multirow{5}{*}[14]{} \\
\hline & $\begin{array}{c}\text { The average size of a primary } \\
\text { neurosphere }\end{array}$ & $175 \pm 2.2 \mu \mathrm{m}$ & $100 \pm 3.2 \mu \mathrm{m}$ & $57 \pm 0.7 \mu \mathrm{m}$ & \\
\hline & $\begin{array}{c}\text { The number of secondary } \\
\text { neurospheres }\end{array}$ & $47 \pm 4.6$ & $7 \pm 1.2$ & Unable to form & \\
\hline & The percentage of nestin + cells & $91.3 \pm 2 \%$ & $78 \pm 1.2 \%$ & $30.3 \pm 6.4 \%$ & \\
\hline & The percentage of $\beta$ III tubulin + cells & $12.5 \pm 0.7 \%$ & $5.6 \pm 0.4 \%$ & $2.4 \pm 0.4 \%$ & \\
\hline \multirow{4}{*}{ Neuronal (9 days) } & The percentage of $\beta$ III tubulin + cells & $94.6 \pm 1.3 \%$ & $95 \pm 1.2 \%$ & \multirow{4}{*}{ ND } & \multirow{4}{*}[15]{} \\
\hline & $\begin{array}{l}\text { The percentage of cells expressing } \\
\text { neuron-specific markers }\end{array}$ & c. $65 \%$ & c. $65 \%$ & & \\
\hline & $\begin{array}{c}\text { The level of constitutively released } \\
\text { dopamine }\end{array}$ & $610 \pm 21.7 \mathrm{pg} / \mathrm{mL}$ & $559 \pm 33.5 \mathrm{pg} / \mathrm{mL}$ & & \\
\hline & $\begin{array}{c}\text { The level of ATP-stimulated release of } \\
\text { dopamine }\end{array}$ & $920 \pm 45.6 \mathrm{pg} / \mathrm{mL}$ & $813.5 \pm 47.7 \mathrm{pg} / \mathrm{mL}$ & & \\
\hline \multirow{4}{*}{ Endothelial (12 days) } & Flk-1 expression & 17-fold increase & 6-fold increase & \multirow{4}{*}{ ND } & \multirow{4}{*}[16]{} \\
\hline & vWF expression & 13-fold increase & 5-fold increase & & \\
\hline & VE-cadherin expression & 16-fold increase & 4.5-fold increase & & \\
\hline & $\begin{array}{l}\text { Total tubule length of network in } \\
\text { Matrigel angiogenesis assay }\end{array}$ & $15 \mathrm{~mm}$ & $11 \mathrm{~mm}$ & & \\
\hline \multirow{3}{*}{ Pancreatic (3 days) } & $\begin{array}{c}\text { Diameter of formed islet-like cell } \\
\text { clusters }\end{array}$ & $\begin{array}{c}\text { Larger } \\
(100-200 \mu \mathrm{m})\end{array}$ & Smaller $(<100 \mu \mathrm{m})$ & \multirow{3}{*}{ ND } & \multirow{3}{*}{ [17] } \\
\hline & $\begin{array}{l}\text { The percentage of differentiated cells } \\
\text { expressing pancreatic-specific marker } \\
\text { C-peptide }\end{array}$ & $53.3 \%$ & $30.9 \%$ & & \\
\hline & $\begin{array}{c}\text { Insulin secretion on day } 1 \text { after } \\
\text { differentiation }\end{array}$ & $14 \mathrm{mIU} / \mathrm{L}$ & $7 \mathrm{mIU} / \mathrm{L}$ & & \\
\hline
\end{tabular}

Interestingly, the plasticity of UC-MSCs may depend on the conditions of pregnancy. UC-MSCs from preeclamptic patients were more committed to neuroglial differentiation: the protein expressions of neuronal (MAP-2) and oligodendrocytic (MBP) markers were significantly increased in cells from preeclampsia versus gestational age-matched controls [80]. At the same time, preterm birth had no effect on neuronal differentiation of UC-MSCs when compared to term delivery [81] but led to a decrease in osteogenic potential [82]. UC-MSCs obtained from gestational diabetes mellitus patients expressed similar levels of CD105, CD90, and CD73 when compared with UC-MSCs from normal pregnant women but showed decreased cell growth and earlier cellular senescence with accumulation of p16 and p53, displayed significantly lower osteogenic and adipogenic differentiation potentials, and, furthermore, exhibited low mitochondrial activity and significantly reduced expression of the mitochondrial function regulatory genes ND2, ND9, COX1, PGC-1 $\alpha$, and TFAM [83]. Thus, impaired metabolism of the maternal organism during pregnancy has a significant impact on the biological properties of neonatal MSCs. This fact should be taken into account when choosing a source of cells for clinical use.

\section{Secretome of UC-MSCs}

MSCs produce a variety of bioactive compounds that supply a paracrine mechanism for their therapeutic activity. However, UC-MSCs' secretome differs significantly from MSCs from other sources (bone marrow and adipose tissue). The most obvious dissimilarity is the almost complete absence of synthesis of the main proangiogenic factor VEGF-A: the level of secretion is $10^{2}$ less than AT-MSCs and $10^{3}$ less than BMMSCs $[59,84,85]$. Wherein, transcription level of VEGF gene expression is detectable [85] and, according to some reports, is very similar to that of BM-MSC [57]. The production of some proangiogenic factors (including angiogenin and PLGF) by UC-MSCs is also reduced, and the production of some antiangiogenic factors (including thrombospondin-2 and endostatin) is increased compared with BM-MSCs and AT-MSCs $[84,85]$. Contrariwise, UC-MSCs expressed higher levels of angiogenic chemokines such as CXCL1, CXCL, 
CXCL5, CXCL6, and CXCL8 and angiogenic growth factors like HGF, bFGF, VEGF-D, PDGF-AA, TGF- $\beta 2$, G-CSF, and TGF- $\beta 2[59,84,86,87]$. Consequently, UC-MSCs realize their proangiogenic capacity by a VEGF-A-independent pathway $[20,85]$.

It has also been reported that UC-MSCs exhibited increased secretion of neurotrophic factors such as bFGF, nerve growth factor (NGF), neurotrophin 3 (NT3), neurotrophin 4 (NT4), and glial-derived neurotrophic factor (GDNF) compared to BM-MSCs and AT-MSCs [14]. Based on these and published data, the authors of the study believe that UC-MSCs could be precommitted to an ectodermal fate.

Additionally, UC-MSCs secrete significantly higher amounts of several important cytokines and hematopoietic growth factors, including G-CSF, GM-CSF, LIF, IL-1 $\alpha$, IL-6, IL-8, and IL-11, compared to BM-MSCs, and thus are better candidates for hematopoietic stem cells expansion [88].

\section{The Immunomodulatory Properties of UC-MSCs}

In 2008, Weiss et al. were the first to investigate the immunomodulatory properties of UC-MSCs. In vitro study supported five main conclusions:

(1) UC-MSCs suppressed the proliferation of Con-Astimulated rat splenocytes (xenograft model) or activated human peripheral blood mononuclear cells (allogeneic model).

(2) UC-MSCs did not stimulate the proliferation of allogeneic or xenogeneic immune cells.

(3) UC-MSCs produced an immunosuppressive isoform of human leukocyte antigen HLA-G6 that inhibited the cytolytic activity of NK cells.

(4) UC-MSCs did not express immune response-related surface antigens CD40, CD80, and CD86, which participated in $\mathrm{T}$ lymphocytes activation.

(5) UC-MSCs produced anti-inflammatory cytokines, which provided their immunomodulatory properties [89].

It is currently believed that the immunomodulatory activity of UC-MSCs is provided by the paracrine mechanism. For example, UC-MSCs produce IL-6 that instructs dendritic cells to acquire tolerogenic phenotypes [90], prostaglandin E2 (PGE2) that suppresses NK cells cytotoxicity [91] and CD4+ and CD8+ T-cell proliferation [92], and indoleamine 2,3-dioxygenase (IDO) that inhibits the differentiation of circulating $\mathrm{T}$ follicular helper cells [93]. In contrast to BMMSCs and AT-MSCs, UC-MSCs secrete anti-inflammatory cytokine IFN- $\alpha$ [84]. After exposure with proinflammatory cytokine IL- $1 \beta$ for 48 hours, UC-MSCs exhibited comparatively elevated expression of immunomodulatory molecules TGF $\beta 1$, IDO, TNF-stimulated gene 6 protein (TSG-6), and PGE2, when compared to MSCs from bone marrow or placenta [22]. PGE2 secreted by activated MSCs drives resident macrophages with $\mathrm{M} 1$ proinflammatory phenotype toward M2 anti-inflammatory phenotype and TSG-6 interacts with
CD44 on resident macrophages to decrease TLR2/NF $\kappa$-B signaling and thereby decrease the secretion of proinflammatory mediators of inflammation. These findings place MSCs (and especially UC-MSCs due to their secretome) at the center of early regulators of inflammation [94].

Interestingly, culture conditions may influence the UCMSCs' immunomodulatory properties: UC-MSCs-mediated suppression of T-cell proliferation in an allogeneic mixed lymphocyte reaction is more effective in xeno-free (containing GMP-certified human serum) and serum-free media than in standard fetal bovine serum-containing cultures. Therefore, the removal of xenogeneic components of the culture medium is important for future clinical study design in regenerative and transplant medicine [95].

\section{Mitochondrial Transfer between UC-MSCs and Damaged Cells}

About ten years ago the unexpected observation that MSCs can rescue cells with nonfunctional mitochondria by the transfer of either mitochondria or mitochondrial DNA was made [96]. The observation had broad implications for the therapeutic potentials of MSCs because failure of mitochondria is an initial event in many diseases, particularly with ischemia and reperfusion of tissues [97].

In a recent study, the capability of UC-MSCs to transfer their own mitochondria into mitochondrial DNA- (mtDNA-) depleted $\rho(0)$ cells was shown. The survival cells had mtDNA identical to that of UC-MSCs, whereas they expressed cellular markers identical to that of $\rho(0)$ cells. Importantly, these $\rho(0)$ plus-UC-MSC-mtDNA cells recovered the expression of mtDNA-encoded proteins and exhibited functional oxygen consumption and respiratory control, as well as the activity of electron transport chain (ETC) complexes I, II, III, and IV. In addition, ETC complex V-inhibitor-sensitive ATP production and metabolic shifting were also recovered. Furthermore, cellular behaviors including attachment-free proliferation, aerobic viability, and oxidative phosphorylation-reliant cellular motility were also regained after mitochondrial transfer by UC-MSCs. The therapeutic effect of UC-MSCs-derived mitochondrial transfer was stably sustained for at least 45 passages [98].

The transfer of mitochondria therefore provided a rational for the therapeutic use of UC-MSCs for ischemic injury or diseases linked to mitochondrial dysfunction.

\section{Tumorigenic Potential of UC-MSCs}

Perinatal stem cells possess the characteristics of both embryonic stem cells and adult stem cells as they possess pluripotency properties, as well as multipotent tissue maintenance; they represent a bridge between embryonic and adult stem cells [99]. Expression of markers of pluripotency in the UCMSCs is higher than in BM-MSCs $[8,11,72]$ but lower than in ESCs $[41,100]$. Perhaps this explains the crucial difference between UC-MSCs and ESCs: UC-MSCs do not induce tumorigenesis, unlike ESCs. In one of the first works devoted to the subject, the tumor-producing capabilities of UC-MSCs were compared with human ESCs using the immunodeficient 
mouse model. Animals that received human ESCs developed teratomas in 6 weeks (s.c. $85 \%$; i.m. 75\%; i.p. 100\%) that contained tissues of ectoderm, mesoderm, and endoderm. No animal that received human UC-MSCs developed tumors or inflammatory reactions at the injection sites when maintained for a prolonged period (20 weeks) [101]. Moreover, it was shown that UC-MSCs could be immortalized by transduction with a lentiviral vector carrying hTERT (human telomerase reverse transcriptase) catalytic subunit gene but even then transfected UC-MSCs showed no transformation into tumors in nude mice [102].

In vitro model of cell culture transformation (cells were grown in the presence of breast and ovarian cancer cell conditioned medium for 30 days) demonstrated that no changes were observed in UC-MSCs' morphology, proliferation rates, or transcriptome compared to BM-MSCs that transformed into tumor-associated fibroblasts [103].

Therefore, human UC-MSCs, being nontumorigenic, have the potential for safe cell-based therapies.

\section{Preclinical Studies regarding the Use of UC-MSCs}

Promising results were obtained in recent preclinical studies regarding the use of UC-MSCs for the treatment of different diseases using animal models. Table 5 shows the most interesting data.

Reports from the early period of MSC-based cell therapy for tissue repair demonstrated that injected MSCs may survive, engraft, and differentiate into specific cell types and repair injured tissues. However, subsequent studies supported the notion that the level of UC-MSCs engraftment in the host organs of recipient animals was low after systemic administration and rather high after local administration. There is little evidence for the differentiation of UC-MSCs into relevant cells; it may be related to xenogeneic transplantation used in most of the studies. Presently, proposed mechanisms of UC-MSCs therapeutic activity include trophic and paracrine effects on cells of the immune system, remodeling of the extracellular matrix, angiogenesis, apoptosis, and stimulation of the migration and proliferation of resident progenitor cells $[18,19,21-29,31,104]$. All of the studies show amazing prospects for clinical use of UC-MSCs.

\section{Clinical Studies regarding the Use of UC-MSCs}

Currently, the FDA has registered dozens of clinical trials (phases 1-3) on the safety and efficacy of allogeneic unmodified UC-MSCs transplantation for the treatment of socially significant diseases. According to https://www.clinicaltrials .gov/ data [105] (search queries "wharton jelly msc" and "umbilical cord msc", results that contain "blood-derived" were excluded), UC-MSCs are used for the treatment of acute myocardial infarction, cardiomyopathies, critical limb ischemia, bronchopulmonary dysplasia in infants, HIV infection, diabetes mellitus types I and II, both acute and chronic liver diseases, autoimmune hepatitis, cirrhosis of various etiologies, ulcerative colitis, severe aplastic anemia, Alzheimer's
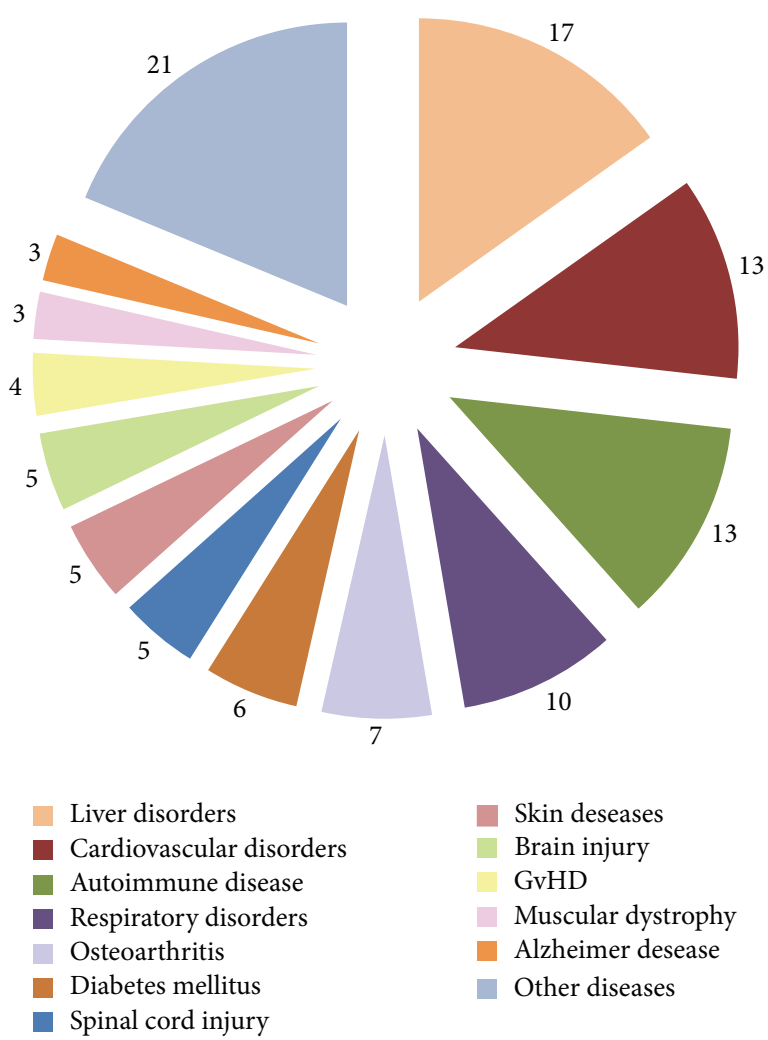

Skin deseases

- Brain injury

GvHD

Muscular dystrophy

- Alzheimer desease

Other diseases

FIgURE 3: Number of clinical trials for UC-MSCs based therapy (https://ClinicalTrials.gov/).

disease, systemic lupus erythematosus, rheumatoid arthritis, myelodysplastic syndrome, hereditary ataxia, spinal cord injury, ankylosing spondylitis, osteoarthritis, multiple sclerosis, Duchenne muscular dystrophy, acute and resistant to steroid therapy "graft versus host" reactions, and other diseases. The diagrammatic representation of clinical applications of UC-MSCs is shown in Figure 3.

At present, the results of only a small part of the clinical studies are published. Table 6 shows the most promising results of clinical trials (phases 2-3).

In all clinical studies UC-MSCs administration had no side-effects except for several cases of fever. In all clinical trials, only allogeneic transplantation of UC-MSCs is studied. This can be explained quite simply: UC-MSCs banking started a few years ago, so a set of recipient groups for autologous transplantation is not possible for the present. However, there is evidence that the efficacy of autologous and allogeneic MSCs transplantation is comparable [106-108].

The results of clinical trials using UC-MSCs are encouraging, particularly for treatment of autoimmune and endocrine diseases.

\section{Requirements for the Standardization of Transplant Based on UC-MSCs}

The main problem with comparing the results of experimental studies and clinical trials is the lack of a standardized protocol for the isolation, expansion, and cryopreservation 


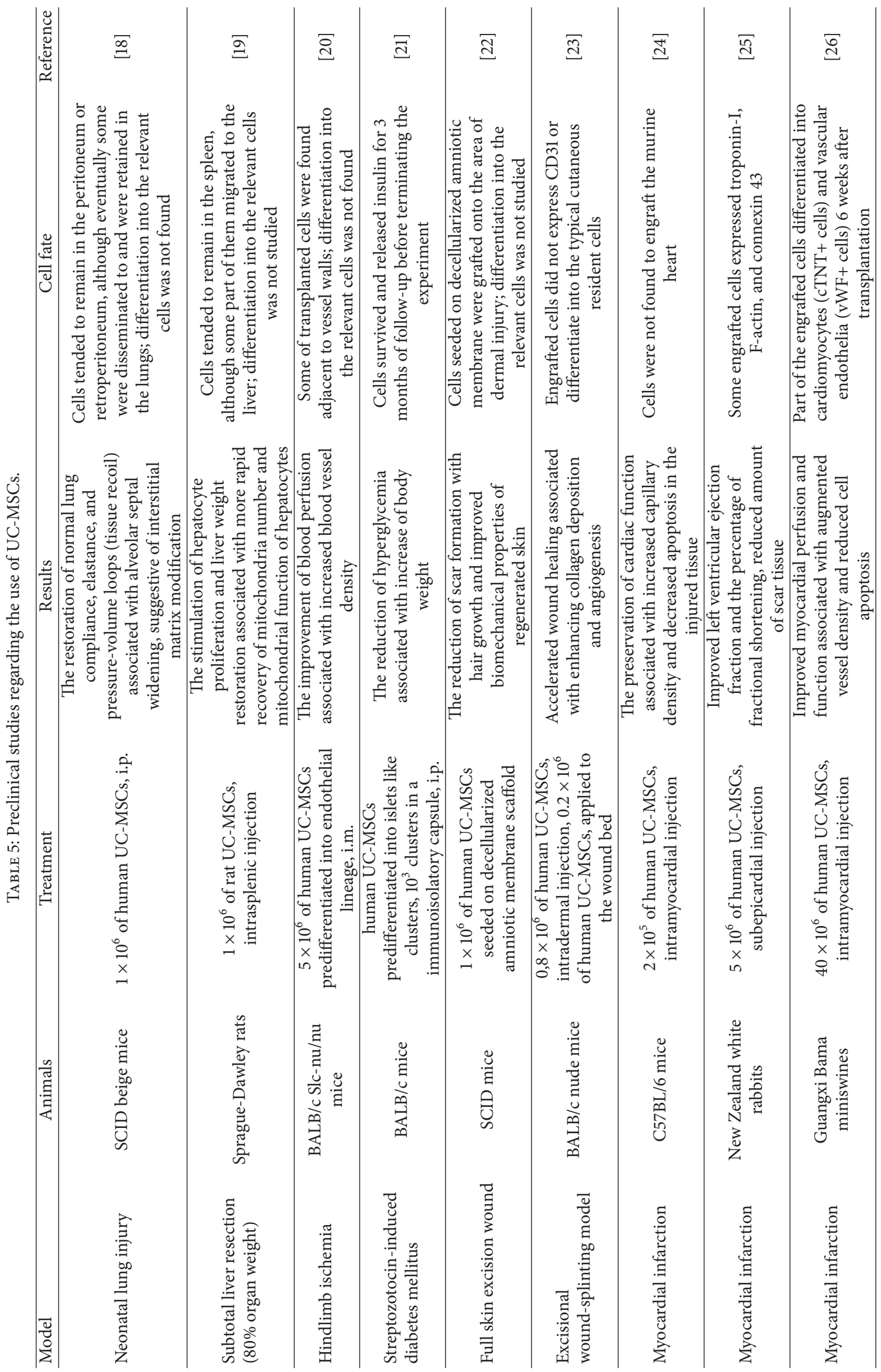




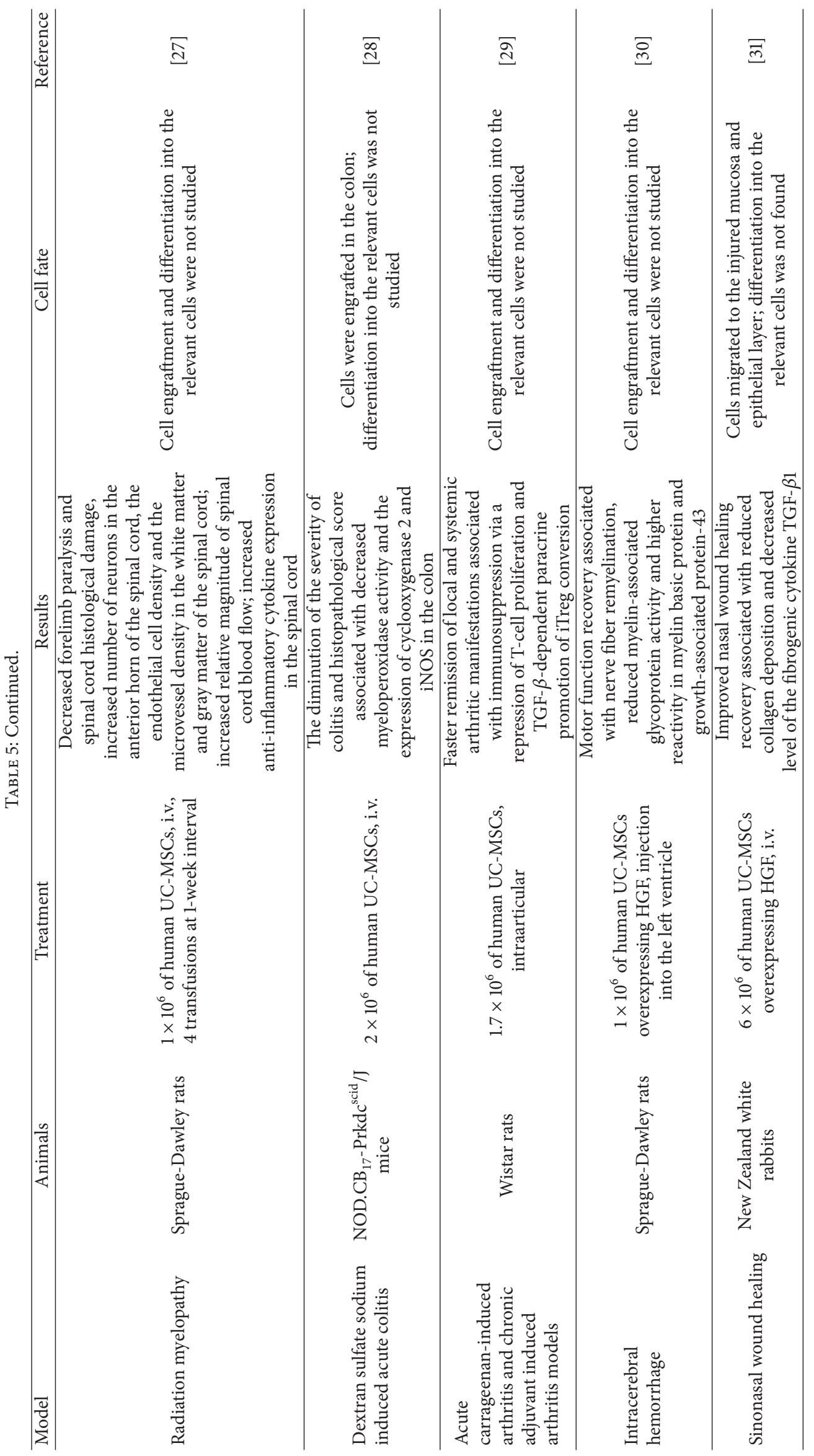


TABLE 6: Clinical studies regarding the use of UC-MSCs.

\begin{tabular}{|c|c|c|c|}
\hline $\begin{array}{l}\text { Disease } \\
\text { Number of clinical trials } \\
\text { (NCT) }\end{array}$ & $\begin{array}{l}\text { The number of recipients } \\
\text { (age) } \\
\text { The number of transplanted } \\
\text { UC-MSCs } \\
\text { The route of administration } \\
\text { The frequency of } \\
\text { administration }\end{array}$ & Main results & Reference \\
\hline $\begin{array}{l}\text { Type } 1 \text { diabetes mellitus } \\
\text { NCT01219465 }\end{array}$ & $\begin{array}{l}15 \text { ( } \leq 25 \text { years }) \\
2,6 \pm 1,2 \times 10^{6} \\
\text { i.v. } \\
\text { Twice, } 4 \text {-week interval }\end{array}$ & $\begin{array}{l}\text { (1) During the whole study ( } 24 \text { months), there was no } \\
\text { statistical difference between treatment and control groups } \\
\text { in mean fasting plasma glucose (FPG) and results of } \\
\text { glutamic acid decarboxylase antibody (GADA) test } \\
\text { In treatment group compared to control group: } \\
\text { (2) Mean postprandial plasma glucose (PPG) levels and } \\
\text { glycated hemoglobin HbAlc levels were lower since month } \\
9 \\
\text { (3) Fasting C-peptide levels and mean C-peptide/glucose } \\
\text { ratio (CPGR) levels were higher since month } 6 \\
\text { (4) The dosage of insulin per day was progressively } \\
\text { reduced since month } 6 \text {. In } 8 \text { patients, the daily insulin } \\
\text { dosage was reduced by more than } 50 \% \text { of the baseline, and } \\
\text { in } 3 \text { patients insulin was discontinued. } \\
\text { (5) No adverse reactions and no ketoacidosis appeared in } \\
\text { treatment group, while in control group ketoacidosis } \\
\text { appeared in } 3 \text { patients }\end{array}$ & [32] \\
\hline $\begin{array}{l}\text { Systemic lupus } \\
\text { erythematosus } \\
\text { NCT01741857 }\end{array}$ & $\begin{array}{l}\text { Six }(15-60 \text { years }) \\
1 \times 10^{6} \text { per } 1 \mathrm{~kg} \\
\text { i.v. } \\
\text { Once }\end{array}$ & $\begin{array}{l}\text { One month after transplantation: } \\
\text { (1) Serum indoleamine 2,3-dioxygenase (IDO) activity } \\
\text { increased } \\
\text { (2) Percentages of peripheral blood CD } 3+C D 4+\text { T-cells } \\
\text { decreased }\end{array}$ & [33] \\
\hline
\end{tabular}

(1) Significant improvements in the SLEDAI (Systemic Lupus Erythematosus Disease Activity Index) score in all patients 3 months after transplantation and in 2 patients 24 months after transplantation

(2) In all patients with lupus nephritis $(n=15)$, proteinuria reduced 3 months after transplantation, 6 months after in 8 patients; 12 months after in 2 patients; 18

Systemic lupus erythematosus NCT00698191 $16(17-55$ years $)$ $1 \times 10^{6}$ per $1 \mathrm{~kg}$ i.v. Once months after in 1 patient

(3) In 13 patients with hypoproteinemia, serum albumin levels increased

(4) In 6 patients with refractory cytopenias, the platelet count increased

(5) The percentage of CD4+FoxP3+ T-cells (Treg cells) in peripheral blood increased

(6) Serum levels of TGF $\beta$ increased, and serum levels of

IL- 4 decreased 3 months after transplantation

(7) There was no significant difference in IL-10 levels between treatment and comparison groups

(1) There were no significant differences in the duration of intubation between treatment and comparison groups

(2) BPD severity was lower in treatment group, regression coefficient 1.7

(3) In treatment group, levels of IL-1 $\beta$, IL-6, IL-8, IL-10,

MMP-9, TNF $\alpha$, and TGF $\beta 1$ in tracheal aspirates at day 7 were significantly reduced compared with those at baseline or at day 3 posttransplantation 
TABLE 6: Continued.

$\begin{array}{ll} & \begin{array}{l}\text { The number of recipients } \\ \text { (age) }\end{array} \\ \text { The number of transplanted } & \text { Main results } \\ \text { Disease } & \text { UC-MSCs } \\ \text { Number of clinical trials } & \begin{array}{l}\text { The route of administration } \\ \text { The frequency of } \\ \text { administration }\end{array} \\ \end{array}$

(1) CD4 T-cell counts and CD4/CD8 ratio increased after 6 months of treatment compared with the individual baseline data as well as with controls

(2) No significant alterations in counts of CD3 and CD8 T-cells, CD19+ B cells, CD3-CD56+ NK cells, CD3+CD56+NK T-cells, Lin-1-HLA-DR+CD11c+ mDCs, Lin-1-HLA-DR+CD123+ pDCs, and $\gamma \delta$ T cells were observed

Seven (26-49 years)

HIV-1

NCT01213186

$0,5 \times 10^{6}$ per $1 \mathrm{~kg}$

i.v.

Three transfusions at 1-month interval
(3) The percentages of naive and central memory T-cells subsets were gradually increased, whereas the effector memory and terminally differentiated effector T-cells subsets were gradually decreased

(4) Significantly decreased PD-1 (programmed cell death 1) expression on total CD4, CD8 T-cells, and HIV-1-specific pentamer + CD8 T-cells at months 6, 9, and 12, and significantly increased BTLA (B-lymphocyte attenuator and T-lymphocyte attenuator) expression levels on total CD4 and CD8 T-cells were found at months 9 and 12 (5) Plasma levels of proinflammatory cytokines IFN- $\alpha 2$, TNF- $\alpha$, IFN- $\gamma$, IL-9 (month 6), IL-1ra, IL-12p70, and IL-6 (months 6 and 12), chemokines MIP-1 $\beta$, IP-10, IL-8, MCP-1, and RANTES (months 6 and 12), growth factors PDGF-BB (month 6), and G-CSF and VEGF (months 6 and 12) levels were significantly reduced

(1) There was a significant decrease in serum alkaline phosphatase and $\gamma$-glutamyltransferase levels at the end of the follow-up period (48 weeks) as compared with baseline

Seven (33-58 years)

$0,5 \times 10^{6}$ per $1 \mathrm{~kg}$

i.v.

(2) No significant changes were observed in serum alanine

Three transfusions at 4-week interval aminotransferase, aspartate aminotransferase, total bilirubin, albumin, prothrombin time activity, international normalized ratio, or immunoglobulin $\mathrm{M}$ levels

(1) The survival rates in patients were significantly increased during the 48-week follow-up period

(2) There were increased levels of serum albumin and cholinesterase (12 weeks after the first transfusion), prothrombin activity (1 week after the first transfusion), hemoglobin level, and platelet counts (36 weeks after the failure $0,5 \times 10^{6}$ per $1 \mathrm{~kg}$ i.v. NCT01218464

Three transfusions at 4-week interval

(3) Serum total bilirubin (1 week after the first transfusion) and alanine aminotransferase (throughout the 48 weeks of follow-up) levels were significantly decreased

(1) The absolute increase in the myocardial viability and perfusion within the infarcted territory was significantly greater than in the placebo group at four months.

(2) The absolute increase in the global left ventricular ejection fraction at 18 months was significantly greater than that in the placebo group. NCT01291329

$6 \times 10^{6}$ Intracoronary infusion Once
(3) The absolute decreases in left ventricular end-systolic volumes and end-diastolic volumes at 18 months were significantly greater than those in the placebo group 
of UC-MSCs [42] and of uniform requirements for the final product. The most complete published list of these requirements includes the following items:

(1) Tests for virology (HIV-1/2, HBV, HCV, HTLV-1/2, HPV, B-19, CMV, and EBV), syphilis, mycoplasma, and sterility being negative.

(2) Phenotype: the percentages of CD73+, CD90+, and CD105+ cells $\geq 98 \%$ and the percentages of CD34-, CD45-, HLA-DR-, CD14- or CD11b-, CD79a-, or CD19- $\leq 2 \%$.

(3) Viability $\geq 80 \%$ after thawing.

(4) The content of endotoxin $<2 \mathrm{EU} / \mathrm{mL}$ and residual bovine serum albumin $<50 \mathrm{ng} /$ package.

(5) No significant upregulation of transcriptase (hTERT) gene and oncogenes during large-scale expansion.

(6) No significant downregulation of tumor suppressor genes during large-scale expansion.

(7) Confirmed potency [109].

\section{UC-MSCs Are Registered Trademark as $\mathrm{UCX}^{\circledR}$}

In the EU, UC-MSCs-based product was registered under the UCX trademark, manufactured by ECBio (Amadora, Portugal). Currently, UCX cells are being used as an active substance for the production of several off-the-shelf biopharmaceutical medicines at the point of initiating clinical trials. Research study for the UCX cells continues toward the use of these cells as an Advanced Therapy Medicinal Product (ATMP) [110].

\section{UC-MSCs Banking for Clinical Use}

Due to the properties demonstrated in vitro and in vivo, UCMSCs have attracted the attention not only of the experimental groups but also of clinicians. It is no wonder that biobanks that had specialized previously only in umbilical cord blood storage introduced a new type of service, the storage of cultured MSCs from umbilical cord tissue. Among these biobanks, there are Cryo-Cell International, Inc. (Tampa Bay, USA), Precious Cells BioBank HQ (London, UK), Reliance Life Sciences (Navi Mumbai, India), Thai HealthBaby (Bangkok, Thailand), Cryosite (Granville, Australia), Pokrovsky Stem Cells Bank (Saint-Petersburg, Russia), and other biobanks. The only restriction is that biomaterial must be obtained by Caesarean section; the total number of stored samples exceeds tens of thousands [109]. It is considered that long-term cryopreservation does not change the biological properties of UC-MSCs [111]. From our point of view, the optimal solution in terms of future clinical use is simultaneous banking of cord blood (as a source of hematopoietic stem cells [4]) and cultured MSCs from umbilical cord tissue [112].

\section{Conclusion}

The human umbilical cord is a source of MSCs that have

(i) a unique combination of prenatal and postnatal MSCs properties;

(ii) no ethical problems with obtaining biomaterial;

(iii) significant proliferative and differentiation potential;

(iv) lack of tumorigenicity;

(v) karyotype stability;

(vi) high immunomodulatory activity.

Currently isolated and cultured umbilical cord MSCs are a promising storage object of the leading biobanks of the world, and the number of registered clinical trials on their use is currently growing.

\section{Abbreviations}

MSCs: Mesenchymal stem cells

BM-MSCs: Bone marrow-derived mesenchymal stem cells

UC-MSCs: Umbilical cord-derived mesenchymal stem cells

ISCT: International Society for Cellular Therapy

ESCs: $\quad$ Embryonic stem cells

AT-MSCs: Adipose tissue-derived mesenchymal stem cells.

\section{Competing Interests}

The authors declare that they have no competing interests.

\section{Authors' Contributions}

Irina Arutyunyan, Andrey Elchaninov, and Andrey Makarov drafted the paper. Timur Fatkhudinov and Irina Arutyunyan outlined, edited, and revised the paper and all authors read and approved the final paper.

\section{Acknowledgments}

This research was supported by Russian Science Foundation, Project no. 16-15-00281. The authors thank Irina Teveleva for final editing. They acknowledge Marina Tumkina for help with paper preparation.

\section{References}

[1] M. Crisan, S. Yap, L. Casteilla et al., "A perivascular origin for mesenchymal stem cells in multiple human organs," Cell Stem Cell, vol. 3, no. 3, pp. 301-313, 2008.

[2] A. Bongso and C.-Y. Fong, "Phenotype and differentiation potential of stromal populations obtained from various zones of human umbilical cord: an overview," Stem Cell Reviews and Reports, vol. 9, no. 2, pp. 226-240, 2013.

[3] "Anatomy and pathology of the umbilical cord," in Pathology of the Human Placenta, K. Benirschke, P. Kaufmann, and R. N. Baergen, Eds., pp. 380-451, Springer, New York, NY, USA, 2006. 
[4] S. Knudtzon, "In vitro growth of granulocytic colonies from circulating cells in human cord blood," Blood, vol. 43, no. 3, pp. 357-361, 1974.

[5] K. D. McElreavey, A. I. Irvine, K. T. Ennis, and W. H. I. McLean, "Isolation, culture and characterisation of fibroblast-like cells derived from the Wharton's jelly portion of human umbilical cord," Biochemical Society Transactions, vol. 19, no. 1, article 29S, 1991.

[6] H.-S. Wang, S.-C. Hung, S.-T. Peng et al., "Mesenchymal stem cells in the Wharton's jelly of the human umbilical cord," STEM CELLS, vol. 22, no. 7, pp. 1330-1337, 2004.

[7] A. K. Batsali, M.-C. Kastrinaki, H. A. Papadaki, and C. Pontikoglou, "Mesenchymal stem cells derived from Wharton's jelly of the umbilical cord: biological properties and emerging clinical applications," Current Stem Cell Research and Therapy, vol. 8, no. 2, pp. 144-155, 2013.

[8] A. Can and S. Karahuseyinoglu, "Concise review: human umbilical cord stroma with regard to the source of fetus-derived stem cells," STEM CELLS, vol. 25, no. 11, pp. 2886-2895, 2007.

[9] R. El Omar, J. Beroud, J.-F. Stoltz, P. Menu, E. Velot, and V. Decot, "Umbilical cord mesenchymal stem cells: the new gold standard for mesenchymal stem cell-based therapies?" Tissue Engineering-Part B: Reviews, vol. 20, no. 5, pp. 523-544, 2014.

[10] C.-Y. Fong, M. Richards, N. Manasi, A. Biswas, and A. Bongso, "Comparative growth behaviour and characterization of stem cells from human Wharton's jelly," Reproductive BioMedicine Online, vol. 15, no. 6, pp. 708-718, 2007.

[11] U. Nekanti, V. B. Rao, A. G. Bahirvani, M. Jan, S. Totey, and M. $\mathrm{Ta}$, "Long-term expansion and pluripotent marker array analysis of Wharton's jelly-derived mesenchymal stem cells," Stem Cells and Development, vol. 19, no. 1, pp. 117-130, 2010.

[12] J. De Kock, M. Najar, J. Bolleyn et al., "Mesoderm-derived stem cells: the link between the transcriptome and their differentiation potential," Stem Cells and Development, vol. 21, no. 18, pp. 3309-3323, 2012.

[13] X. Li, J. Bai, X. Ji, R. Li, Y. Xuan, and Y. Wang, "Comprehensive characterization of four different populations of human mesenchymal stem cells as regards their immune properties, proliferation and differentiation," International Journal of Molecular Medicine, vol. 34, no. 3, pp. 695-704, 2014.

[14] S. Balasubramanian, C. Thej, P. Venugopal et al., "Higher propensity of Wharton's jelly derived mesenchymal stromal cells towards neuronal lineage in comparison to those derived from adipose and bone marrow," Cell Biology International, vol. 37, no. 5, pp. 507-515, 2013.

[15] I. Datta, S. Mishra, L. Mohanty, S. Pulikkot, and P. G. Joshi, "Neuronal plasticity of human Wharton's jelly mesenchymal stromal cells to the dopaminergic cell type compared with human bone marrow mesenchymal stromal cells," Cytotherapy, vol. 13, no. 8, pp. 918-932, 2011.

[16] M.-Y. Chen, P.-C. Lie, Z.-L. Li, and X. Wei, "Endothelial differentiation of Wharton's jelly-derived mesenchymal stem cells in comparison with bone marrow-derived mesenchymal stem cells," Experimental Hematology, vol. 37, no. 5, pp. 629-640, 2009.

[17] L.-F. Wu, N.-N. Wang, Y.-S. Liu, and X. Wei, "Differentiation of Wharton's jelly primitive stromal cells into insulin-producing cells in comparison with bone marrow mesenchymal stem cells," Tissue Engineering Part A, vol. 15, no. 10, pp. 2865-2873, 2009.
[18] L. Liu, Q. Mao, S. Chu et al., "Intranasal versus intraperitoneal delivery of human umbilical cord tissue-derived cultured mesenchymal stromal cells in a murine model of neonatal lung injury," American Journal of Pathology, vol. 184, no. 12, pp. 33443358, 2014.

[19] A. V. El'chaninov, M. A. Volodina, I. V. Arutyunyan et al., "Effect of multipotent stromal cells on the function of cell mitochondria in regenerating liver," Bulletin of Experimental Biology and Medicine, vol. 158, no. 4, pp. 566-572, 2015.

[20] M. Choi, H.-S. Lee, P. Naidansaren et al., "Proangiogenic features of Wharton's jelly-derived mesenchymal stromal/stem cells and their ability to form functional vessels," International Journal of Biochemistry and Cell Biology, vol. 45, no. 3, pp. 560570, 2013.

[21] S. S. Kadam and R. R. Bhonde, "Islet neogenesis from the constitutively nestin expressing human umbilical cord matrix derived mesenchymal stem cells," Islets, vol. 2, no. 2, pp. 112-120, 2010.

[22] V. Sabapathy, B. Sundaram, V. M. Sreelakshmi, P. Mankuzhy, and S. Kumar, "Human Wharton's jelly mesenchymal stem cells plasticity augments scar-free skin wound healing with hair growth," PLoS ONE, vol. 9, no. 4, Article ID e93726, 2014.

[23] R. Shohara, A. Yamamoto, S. Takikawa et al., "Mesenchymal stromal cells of human umbilical cord Wharton's jelly accelerate wound healing by paracrine mechanisms," Cytotherapy, vol. 14, no. 10, pp. 1171-1181, 2012.

[24] D. S. Nascimento, D. Mosqueira, L. M. Sousa et al., "Human umbilical cord tissue-derived mesenchymal stromal cells attenuate remodeling after myocardial infarction by proangiogenic, antiapoptotic, and endogenous cell-activation mechanisms," Stem Cell Research and Therapy, vol. 5, no. 1, article 5, 2014.

[25] M. Latifpour, S. N. Nematollahi-Mahani, M. Deilamy et al., "Improvement in cardiac function following transplantation of human umbilical cord matrix-derived mesenchymal cells," Cardiology, vol. 120, no. 1, pp. 9-18, 2011.

[26] W. Zhang, X. Liu, L. Yang et al., "Wharton's jelly-derived mesenchymal stem cells promote myocardial regeneration and cardiac repair after miniswine acute myocardial infarction," Coronary Artery Disease, vol. 24, no. 7, pp. 549-558, 2013.

[27] L. Wei, J. Zhang, X.-B. Xiao et al., "Multiple injections of human umbilical cord-derived mesenchymal stromal cells through the tail vein improve microcirculation and the microenvironment in a rat model of radiation myelopathy," Journal of Translational Medicine, vol. 12, no. 1, article 246, 2014.

[28] Y. Lin, L. Lin, Q. Wang et al., “Transplantation of human umbilical mesenchymal stem cells attenuates dextran sulfate sodium-induced colitis in mice," Clinical and Experimental Pharmacology and Physiology, vol. 42, no. 1, pp. 76-86, 2015.

[29] J. M. Santos, R. N. Bárcia, S. I. Simões et al., "The role of human umbilical cord tissue-derived mesenchymal stromal cells (UCX ${ }^{\circledR}$ ) in the treatment of inflammatory arthritis," Journal of Translational Medicine, vol. 11, article 18, 2013.

[30] A. M. Liu, G. Lu, K. S. Tsang et al., "Umbilical cord-derived mesenchymal stem cells with forced expression of hepatocyte growth factor enhance remyelination and functional recovery in a rat intracerebral hemorrhage model," Neurosurgery, vol. 67, no. 2, pp. 357-365, 2010.

[31] J. Li, C.-Q. Zheng, Y. Li, C. Yang, H. Lin, and H.-G. Duan, "Hepatocyte growth factor gene-modified mesenchymal stem cells augment sinonasal wound healing," Stem Cells and Development, vol. 24, no. 15, pp. 1817-1830, 2015.

[32] J. Hu, X. Yu, Z. Wang et al., "Long term effects of the implantation of Wharton's jelly-derived mesenchymal stem cells from 
the umbilical cord for newly-onset type 1 diabetes mellitus," Endocrine Journal, vol. 60, no. 3, pp. 347-357, 2013.

[33] D. Wang, X. Feng, L. Lu et al., "A CD8 T cell/indoleamine 2,3-dioxygenase axis is required for mesenchymal stem cell suppression of human systemic lupus erythematosus," Arthritis \& Rheumatology, vol. 66, no. 8, pp. 2234-2245, 2014.

[34] L. Sun, D. Wang, J. Liang et al., "Umbilical cord mesenchymal stem cell transplantation in severe and refractory systemic lupus erythematosus," Arthritis and Rheumatism, vol. 62, no. 8, pp. 2467-2475, 2010.

[35] Y. S. Chang, S. Y. Ahn, H. S. Yoo et al., "Mesenchymal stem cells for bronchopulmonary dysplasia: phase 1 dose-escalation clinical trial," Journal of Pediatrics, vol. 164, no. 5, pp. 966-972.e6, 2014.

[36] Z. Zhang, J. Fu, X. Xu et al., "Safety and immunological responses to human mesenchymal stem cell therapy in difficultto-treat HIV-1-infected patients," AIDS, vol. 27, no. 8, pp. 12831293, 2013.

[37] L. Wang, J. Li, H. Liu et al., "A pilot study of umbilical cord-derived mesenchymal stem cell transfusion in patients with primary biliary cirrhosis," Journal of Gastroenterology and Hepatology, vol. 28, supplement 1, pp. 85-92, 2013.

[38] M. Shi, Z. Zhang, R. Xu et al., "Human mesenchymal stem cell transfusion is safe and improves liver function in acute-onchronic liver failure patients," Stem Cells Translational Medicine, vol. 1, no. 10, pp. 725-731, 2012.

[39] L. R. Gao, Y. Chen, N. K. Zhang et al., "Intracoronary infusion of Wharton's jelly-derived mesenchymal stem cells in acute myocardial infarction: double-blind, randomized controlled trial," BMC Medicine, vol. 13, article 162, 2015.

[40] M. Dominici, K. Le Blanc, I. Mueller et al., "Minimal criteria for defining multipotent mesenchymal stromal cells. The International Society for Cellular Therapy position statement," Cytotherapy, vol. 8, no. 4, pp. 315-317, 2006.

[41] X.-Y. Wang, Y. Lan, W.-Y. He et al., "Identification of mesenchymal stem cells in aorta-gonad-mesonephros and yolk sac of human embryos," Blood, vol. 111, no. 4, pp. 2436-2443, 2008.

[42] D.-R. Li and J.-H. Cai, "Methods of isolation, expansion, differentiating induction and preservation of human umbilical cord mesenchymal stem cells," Chinese Medical Journal, vol. 125, no. 24, pp. 4504-4510, 2012.

[43] D. Trivanović, J. Kocić, S. Mojsilović et al., "Mesenchymal stem cells isolated from peripheral blood and umbilical cord Wharton's Jelly," Srpski Arhiv za Celokupno Lekarstvo, vol. 141, no. 3-4, pp. 178-186, 2013.

[44] Y. Mori, J. Ohshimo, T. Shimazu et al., "Improved explant method to isolate umbilical cord-derived mesenchymal stem cells and their immunosuppressive properties," Tissue Engineering Part C: Methods, vol. 21, no. 4, pp. 367-372, 2015.

[45] P. Salehinejad, N. B. Alitheen, A. M. Ali et al., "Comparison of different methods for the isolation of mesenchymal stem cells from human umbilical cord Wharton's jelly," In Vitro Cellular and Developmental Biology-Animal, vol. 48, no. 2, pp. 75-83, 2012.

[46] Y.-F. Han, R. Tao, T.-J. Sun, J.-K. Chai, G. Xu, and J. Liu, "Optimization of human umbilical cord mesenchymal stem cell isolation and culture methods," Cytotechnology, vol. 65, no. 5, pp. 819-827, 2013.

[47] T. Margossian, L. Reppel, N. Makdissy, J.-F. Stoltz, D. Bensoussan, and C. Huselstein, "Mesenchymal stem cells derived from Wharton's jelly: comparative phenotype analysis between tissue and in vitro expansion," BioMedical Materials and Engineering, vol. 22, no. 4, pp. 243-254, 2012.

[48] I. Majore, P. Moretti, F. Stahl, R. Hass, and C. Kasper, "Growth and differentiation properties of mesenchymal stromal cell populations derived from whole human umbilical cord," Stem Cell Reviews and Reports, vol. 7, no. 1, pp. 17-31, 2011.

[49] J. Hua, J. Gong, H. Meng et al., "Comparison of different methods for the isolation of mesenchymal stem cells from umbilical cord matrix: proliferation and multilineage differentiation as compared to mesenchymal stem cells from umbilical cord blood and bone marrow," Cell Biology International, vol. 38, no. 2, pp. 198-210, 2014.

[50] F. V. Paladino, J. S. Peixoto-Cruz, C. Santacruz-Perez, and A. C. Goldberg, "Comparison between isolation protocols highlights intrinsic variability of human umbilical cord mesenchymal cells," Cell and Tissue Banking, vol. 17, no. 1, pp. 123-136, 2016.

[51] F. Hendijani, H. Sadeghi-Aliabadi, and S. Haghjooy Javanmard, "Comparison of human mesenchymal stem cells isolated by explant culture method from entire umbilical cord and Wharton's jelly matrix," Cell and Tissue Banking, vol. 15, no. 4, pp. 555565, 2014.

[52] K. Bieback and I. Brinkmann, "Mesenchymal stromal cells from human perinatal tissues: from biology to cell therapy," World Journal of Stem Cells, vol. 2, no. 4, pp. 81-92, 2010.

[53] D. L. Troyer and M. L. Weiss, "Concise review: Wharton's jellyderived cells are a primitive stromal cell population," Stem Cells, vol. 26, no. 3, pp. 591-599, 2008.

[54] C. T. Vangsness Jr., H. Sternberg, and L. Harris, "Umbilical cord tissue offers the greatest number of harvestable mesenchymal stem cells for research and clinical application: a literature review of different harvest sites," Arthroscopy, vol. 31, no. 9, pp. 1836-1843, 2015.

[55] T. K. Chatzistamatiou, A. C. Papassavas, E. Michalopoulos et al., "Optimizing isolation culture and freezing methods to preserve Wharton's jelly's mesenchymal stem cell (MSC) properties: an MSC banking protocol validation for the Hellenic Cord Blood Bank," Transfusion, vol. 54, no. 12, pp. 3108-3120, 2014.

[56] M. Badowski, A. Muise, and D. T. Harris, "Mixed effects of longterm frozen storage on cord tissue stem cells," Cytotherapy, vol. 16, no. 9, pp. 1313-1321, 2014.

[57] L.-L. Lu, Y.-J. Liu, S.-G. Yang et al., "Isolation and characterization of human umbilical cord mesenchymal stem cells with hematopoiesis-supportive function and other potentials," Haematologica, vol. 91, no. 8, pp. 1017-1026, 2006.

[58] A. Shaer, N. Azarpira, M. H. Aghdaie, and E. Esfandiari, "Isolation and characterization of human mesenchymal stromal cells derived from placental decidua basalis; umbilical cord wharton's jelly and amniotic membrane," Pakistan Journal of Medical Sciences, vol. 30, no. 5, pp. 1022-1026, 2014.

[59] H. Wegmeyer, A.-M. Bröske, M. Leddin et al., "Mesenchymal stromal cell characteristics vary depending on their origin," Stem Cells and Development, vol. 22, no. 19, pp. 2606-2618, 2013.

[60] S. Karahuseyinoglu, O. Cinar, E. Kilic et al., "Biology of stem cells in human umbilical cord stroma: in situ and in vitro surveys," Stem Cells, vol. 25, no. 2, pp. 319-331, 2007.

[61] Z.-B. Ruan, L. Zhu, Y.-G. Yin, and G.-C. Chen, "Karyotype stability of human umbilical cord-derived mesenchymal stem cells during in vitro culture," Experimental and Therapeutic Medicine, vol. 8, no. 5, pp. 1508-1512, 2014. 
[62] G. Chen, A. Yue, Z. Ruan et al., "Human umbilical cord-derived mesenchymal stem cells do not undergo malignant transformation during long-term culturing in serum-free medium," PLoS ONE, vol. 9, no. 6, Article ID e98565, 2014.

[63] Z. Shi, L. Zhao, G. Qiu, R. He, and M. S. Detamore, "The effect of extended passaging on the phenotype and osteogenic potential of human umbilical cord mesenchymal stem cells," Molecular and Cellular Biochemistry, vol. 401, no. 1-2, pp. 155-164, 2015.

[64] S. S. Kadam, S. Tiwari, and R. R. Bhonde, "Simultaneous isolation of vascular endothelial cells and mesenchymal stem cells from the human umbilical cord," In Vitro Cellular and Developmental Biology-Animal, vol. 45, no. 1-2, pp. 23-27, 2009.

[65] T. Bakhshi, R. C. Zabriskie, S. Bodie et al., "Mesenchymal stem cells from the Wharton's jelly of umbilical cord segments provide stromal support for the maintenance of cord blood hematopoietic stem cells during long-term ex vivo culture," Transfusion, vol. 48, no. 12, pp. 2638-2644, 2008.

[66] D. Majumdar, R. Bhonde, and I. Datta, "Influence of ischemic microenvironment on human Wharton's Jelly mesenchymal stromal cells," Placenta, vol. 34, no. 8, pp. 642-649, 2013.

[67] C. Tantrawatpan, S. Manochantr, P. Kheolamai, Y. U-Pratya, A. Supokawe, and S. Issaragrisil, "Pluripotent gene expression in mesenchymal stem cells from human umbilical cord Wharton's jelly and their differentiation potential to neural-like cells," Journal of the Medical Association of Thailand, vol. 96, no. 9, pp. 1208-1217, 2013.

[68] K. Drela, A. Sarnowska, P. Siedlecka et al., "Low oxygen atmosphere facilitates proliferation and maintains undifferentiated state of umbilical cord mesenchymal stem cells in an hypoxia inducible factor-dependent manner," Cytotherapy, vol. 16, no. 7, pp. 881-892, 2014.

[69] F. Amiri, R. Halabian, M. D. Harati et al., "Positive selection of wharton's jelly-derived CD105+ cells by MACS technique and their subsequent cultivation under suspension culture condition: a simple, versatile culturing method to enhance the multipotentiality of mesenchymal stem cells," Hematology, vol. 20, no. 4, pp. 208-216, 2015.

[70] J. Xu, W. Liao, D. Gu et al., "Neural ganglioside GD2 identifies a subpopulation of mesenchymal stem cells in umbilical cord," Cellular Physiology and Biochemistry, vol. 23, no. 4-6, pp. 415424, 2009.

[71] J.-Y. Hsieh, Y.-S. Fu, S.-J. Chang, Y.-H. Tsuang, and H.-W. Wang, "Functional module analysis reveals differential osteogenic and stemness potentials in human mesenchymal stem cells from bone marrow and Wharton's Jelly of umbilical cord," Stem Cells and Development, vol. 19, no. 12, pp. 1895-1910, 2010.

[72] Y. Han, J. Chai, T. Sun, D. Li, and R. Tao, "Differentiation of human umbilical cord mesenchymal stem cells into dermal fibroblasts in vitro," Biochemical and Biophysical Research Communications, vol. 413, no. 4, pp. 561-565, 2011.

[73] H. Wang, T. Zhao, F. Xu et al., "How important is differentiation in the therapeutic effect of mesenchymal stromal cells in liver disease?” Cytotherapy, vol. 16, no. 3, pp. 309-318, 2014.

[74] S. Yang, K. Ma, C. Feng et al., "Capacity of human umbilical cord-derived mesenchymal stem cells to differentiate into sweat gland-like cells: A Preclinical Study," Frontiers of Medicine in China, vol. 7, no. 3, pp. 345-353, 2013.

[75] Y. Chen, Y. Yu, L. Chen et al., "Human umbilical cord mesenchymal stem cells: a new therapeutic option for tooth regeneration," Stem Cells International, vol. 2015, Article ID 549432, 11 pages, 2015.
[76] N. Li, S. Pan, H. Zhu, H. Mu, W. Liu, and J. Hua, "BMP4 promotes SSEA- $1^{+}$hUC-MSC differentiation into male germ-like cells in vitro," Cell Proliferation, vol. 47, no. 4, pp. 299-309, 2014.

[77] M. Latifpour, Y. Shakiba, F. Amidi, Z. Mazaheri, and A. Sobhani, "Differentiation of human umbilical cord matrixderived mesenchymal stem cells into germ-like cells," Avicenna Journal of Medical Biotechnology, vol. 6, no. 4, pp. 218-227, 2014.

[78] J.-F. Li, H.-L. Yin, A. Shuboy et al., "Differentiation of hUCMSC into dopaminergic-like cells after transduction with hepatocyte growth factor," Molecular and Cellular Biochemistry, vol. 381, no. 1-2, pp. 183-190, 2013.

[79] X. Wei, G. Peng, S. Zheng, and X. Wu, "Differentiation of umbilical cord mesenchymal stem cells into steroidogenic cells in comparison to bone marrow mesenchymal stem cells," Cell Proliferation, vol. 45, no. 2, pp. 101-110, 2012.

[80] M. Joerger-Messerli, E. Brühlmann, A. Bessire et al., "Preeclampsia enhances neuroglial marker expression in umbilical cord Wharton's jelly-derived mesenchymal stem cells," Journal of Maternal-Fetal and Neonatal Medicine, vol. 28, no. 4, pp. 464469, 2015.

[81] M. Messerli, A. Wagner, R. Sager et al., "Stem cells from umbilical cord Wharton's jelly from preterm birth have neuroglial differentiation potential," Reproductive Sciences, vol. 20, no. 12, pp. 1455-1464, 2013.

[82] L. Penolazzi, R. Vecchiatini, S. Bignardi et al., "Influence of obstetric factors on osteogenic potential of umbilical cordderived mesenchymal stem cells," Reproductive Biology and Endocrinology, vol. 7, article 106, 2009.

[83] J. Kim, Y. Piao, Y. K. Pak et al., "Umbilical cord mesenchymal stromal cells affected by gestational diabetes mellitus display premature aging and mitochondrial dysfunction," Stem Cells and Development, vol. 24, no. 5, pp. 575-586, 2015.

[84] P. R. Amable, M. V. T. Teixeira, R. B. V. Carias, J. M. Granjeiro, and R. Borojevic, "Protein synthesis and secretion in human mesenchymal cells derived from bone marrow, adipose tissue and Wharton's jelly," Stem Cell Research and Therapy, vol. 5, no. 2, article 53, 2014.

[85] P. Kuchroo, V. Dave, A. Vijayan, C. Viswanathan, and D. Ghosh, "Paracrine factors secreted by umbilical cord-derived mesenchymal stem cells induce angiogenesis in vitro by a VEGFindependent pathway," Stem Cells and Development, vol. 24, no. 4, pp. 437-450, 2015.

[86] P. R. Amable, M. V. Teixeira, R. B. Carias, J. M. Granjeiro, and R. Borojevic, "Gene expression and protein secretion during human mesenchymal cell differentiation into adipogenic cells," BMC Cell Biology, vol. 15, no. 1, article 46, 2014.

[87] S. Balasubramanian, P. Venugopal, S. Sundarraj, Z. Zakaria, A. S. Majumdar, and M. Ta, "Comparison of chemokine and receptor gene expression between Wharton's jelly and bone marrow-derived mesenchymal stromal cells," Cytotherapy, vol. 14, no. 1, pp. 26-33, 2012.

[88] R. Friedman, M. Betancur, L. Boissel, H. Tuncer, C. Cetrulo, and H. Klingemann, "Umbilical cord mesenchymal stem cells: adjuvants for human cell transplantation," Biology of Blood and Marrow Transplantation, vol. 13, no. 12, pp. 1477-1486, 2007.

[89] M. L. Weiss, C. Anderson, S. Medicetty et al., "Immune properties of human umbilical cord Wharton's jelly-derived cells," Stem Cells, vol. 26, no. 11, pp. 2865-2874, 2008.

[90] Y. Deng, S. Yi, G. Wang et al., "Umbilical cord-derived mesenchymal stem cells instruct dendritic cells to acquire tolerogenic phenotypes through the IL-6-mediated upregulation of 
SOCS1," Stem Cells and Development, vol. 23, no. 17, pp. 20802092, 2014.

[91] D. Chatterjee, N. Marquardt, D. M. Tufa et al., "Role of gammasecretase in human umbilical-cord derived mesenchymal stem cell mediated suppression of NK cell cytotoxicity," Cell Communication and Signaling, vol. 12, no. 1, article 63, 2014.

[92] M. Najar, G. Raicevic, H. I. Boufker et al., "Mesenchymal stromal cells use PGE2 to modulate activation and proliferation of lymphocyte subsets: combined comparison of adipose tissue, Wharton's Jelly and bone marrow sources," Cellular Immunology, vol. 264, no. 2, pp. 171-179, 2010.

[93] R. Liu, D. Su, M. Zhou, X. Feng, X. Li, and L. Sun, "Umbilical cord mesenchymal stem cells inhibit the differentiation of circulating $\mathrm{T}$ follicular helper cells in patients with primary Sjögren's syndrome through the secretion of indoleamine 2,3dioxygenase," Rheumatology, vol. 54, no. 2, pp. 332-342, 2015.

[94] D. J. Prockop, "Concise review: two negative feedback loops place mesenchymal stem/stromal cells at the center of early regulators of inflammation," Stem Cells, vol. 31, no. 10, pp. 20422046, 2013.

[95] I. Hartmann, T. Hollweck, S. Haffner et al., "Umbilical cord tissue-derived mesenchymal stem cells grow best under GMPcompliant culture conditions and maintain their phenotypic and functional properties," Journal of Immunological Methods, vol. 363, no. 1, pp. 80-89, 2010.

[96] J. L. Spees, S. D. Olson, M. J. Whitney, and D. J. Prockop, "Mitochondrial transfer between cells can rescue aerobic respiration," Proceedings of the National Academy of Sciences of the United States of America, vol. 103, no. 5, pp. 1283-1288, 2006.

[97] D. J. Prockop and J. Y. Oh, "Medical therapies with adult stem/progenitor cells (MSCs): a backward journey from dramatic results in vivo to the cellular and molecular explanations," Journal of Cellular Biochemistry, vol. 113, no. 5, pp. 1460-1469, 2012.

[98] H.-Y. Lin, C.-W. Liou, S.-D. Chen et al., "Mitochondrial transfer from Wharton's jelly-derived mesenchymal stem cells to mitochondria-defective cells recaptures impaired mitochondrial function," Mitochondrion, vol. 22, pp. 31-44, 2015.

[99] R. R. Taghizadeh, K. J. Cetrulo, and C. L. Cetrulo, "Wharton's Jelly stem cells: future clinical applications," Placenta, vol. 32, supplement 4, pp. S311-S315, 2011.

[100] C.-Y. Fong, L.-L. Chak, A. Biswas et al., "Human Wharton's jelly stem cells have unique transcriptome profiles compared to human embryonic stem cells and other mesenchymal stem cells," Stem Cell Reviews and Reports, vol. 7, no. 1, pp. 1-16, 2011.

[101] K. Gauthaman, C.-Y. Fong, C.-A. Suganya et al., "Extraembryonic human Wharton's jelly stem cells do not induce tumorigenesis, unlike human embryonic stem cells," Reproductive BioMedicine Online, vol. 24, no. 2, pp. 235-246, 2012.

[102] X.-J. Liang, X.-J. Chen, D.-H. Yang, S.-M. Huang, G.-D. Sun, and Y.-P. Chen, "Differentiation of human umbilical cord mesenchymal stem cells into hepatocyte-like cells by hTERT gene transfection in vitro," Cell Biology International, vol. 36, no. 2, pp. 215-221, 2012.

[103] A. Subramanian, G. Shu-Uin, K.-S. Ngo et al., "Human umbilical cord Wharton's jelly mesenchymal stem cells do not transform to tumor-associated fibroblasts in the presence of breast and ovarian cancer cells unlike bone marrow mesenchymal stem cells," Journal of Cellular Biochemistry, vol. 113, no. 6, pp. 1886-1895, 2012.

[104] R. Donders, M. Vanheusden, J. F. J. Bogie et al., "Human Wharton's jelly-derived stem cells display immunomodulatory properties and transiently improve rat experimental autoimmune encephalomyelitis," Cell Transplantation, vol. 24, no. 10, pp. 2077-2098, 2015.

[105] Database of publicly and privately supported clinical studies of human participants, http://www.clinicaltrials.gov/.

[106] L. Planka, P. Gal, H. Kecova et al., "Allogeneic and autogenous transplantations of MSCs in treatment of the physeal bone bridge in rabbits," BMC Biotechnology, vol. 8, article 70, 2008.

[107] Y. L. Kasamon, R. J. Jones, L. F. Diehl et al., "Outcomes of autologous and allogeneic blood or marrow transplantation for mantle cell lymphoma," Biology of Blood and Marrow Transplantation, vol. 11, no. 1, pp. 39-46, 2005.

[108] K. Ashfaq, I. Yahaya, C. Hyde et al., "Clinical effectiveness and cost-effectiveness of stem cell transplantation in the management of acute leukaemia: a systematic review," Health Technology Assessment, vol. 14, no. 54, pp. 1-172, 2010.

[109] L. Liang and Z. C. Han, "Regenerative medicine and cell therapy," in Umbilical Cord Mesenchymal Stem Cells: Biology and Clinical Application, J. F. Stoltz, Ed., pp. 62-70, IOS Press BV, Amsterdam, The Netherlands, 2012.

[110] J. P. Martins, J. M. Santos, J. M. de Almeida et al., “Towards an advanced therapy medicinal product based on mesenchymal stromal cells isolated from the umbilical cord tissue: quality and safety data," Stem Cell Research and Therapy, vol. 5, no. 1, article 9, 2014

[111] K. Cooper and C. Viswanathan, "Establishment of a mesenchymal stem cell bank," Stem Cells International, vol. 2011, Article ID 905621, 8 pages, 2011.

[112] M. Secco, E. Zucconi, N. M. Vieira et al., "Mesenchymal stem cells from umbilical cord: do not discard the cord!," Neuromuscular Disorders, vol. 18, no. 1, pp. 17-18, 2008. 

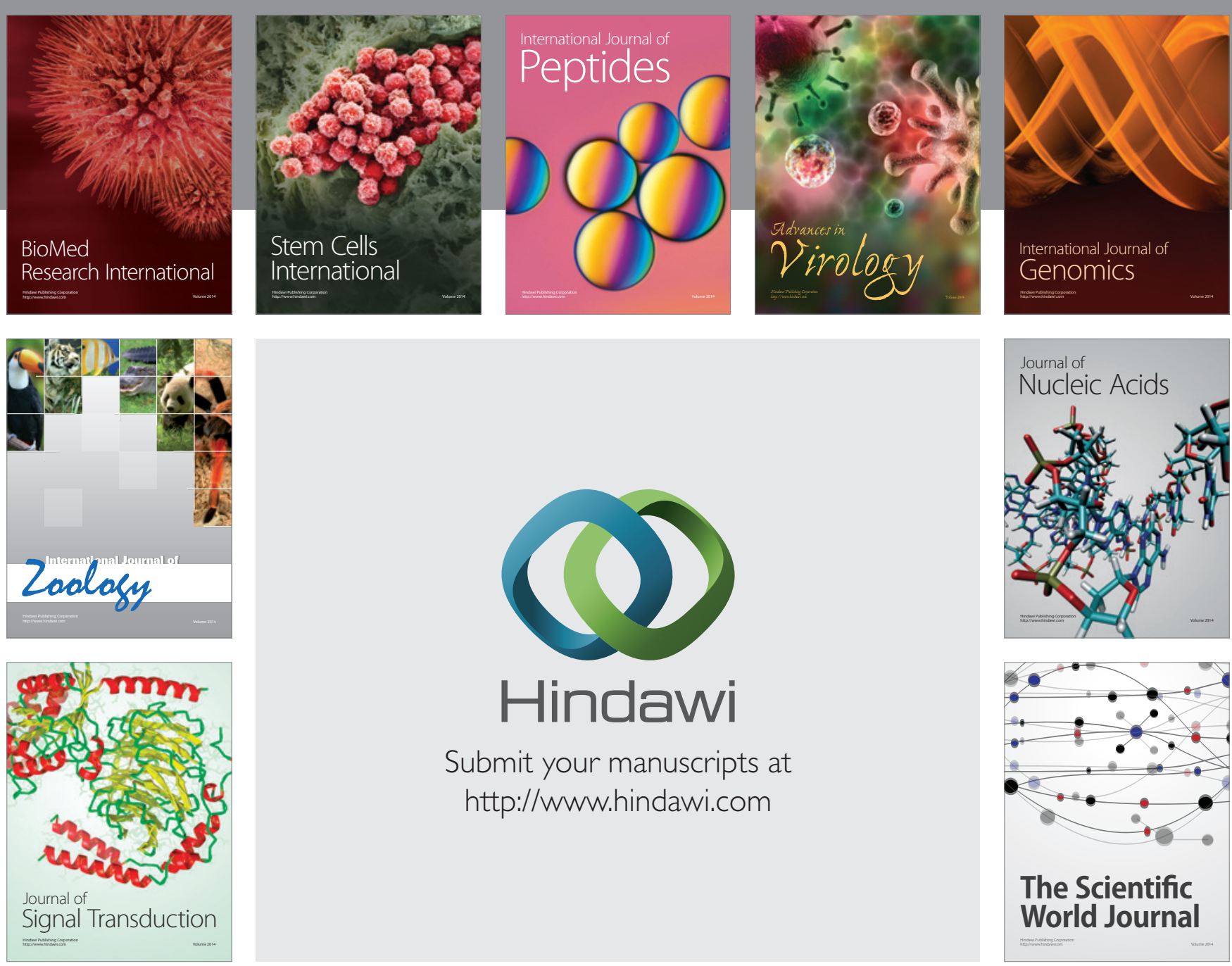

Submit your manuscripts at

http://www.hindawi.com
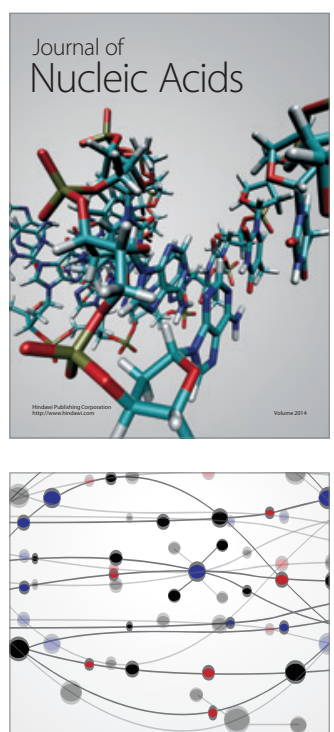

The Scientific World Journal
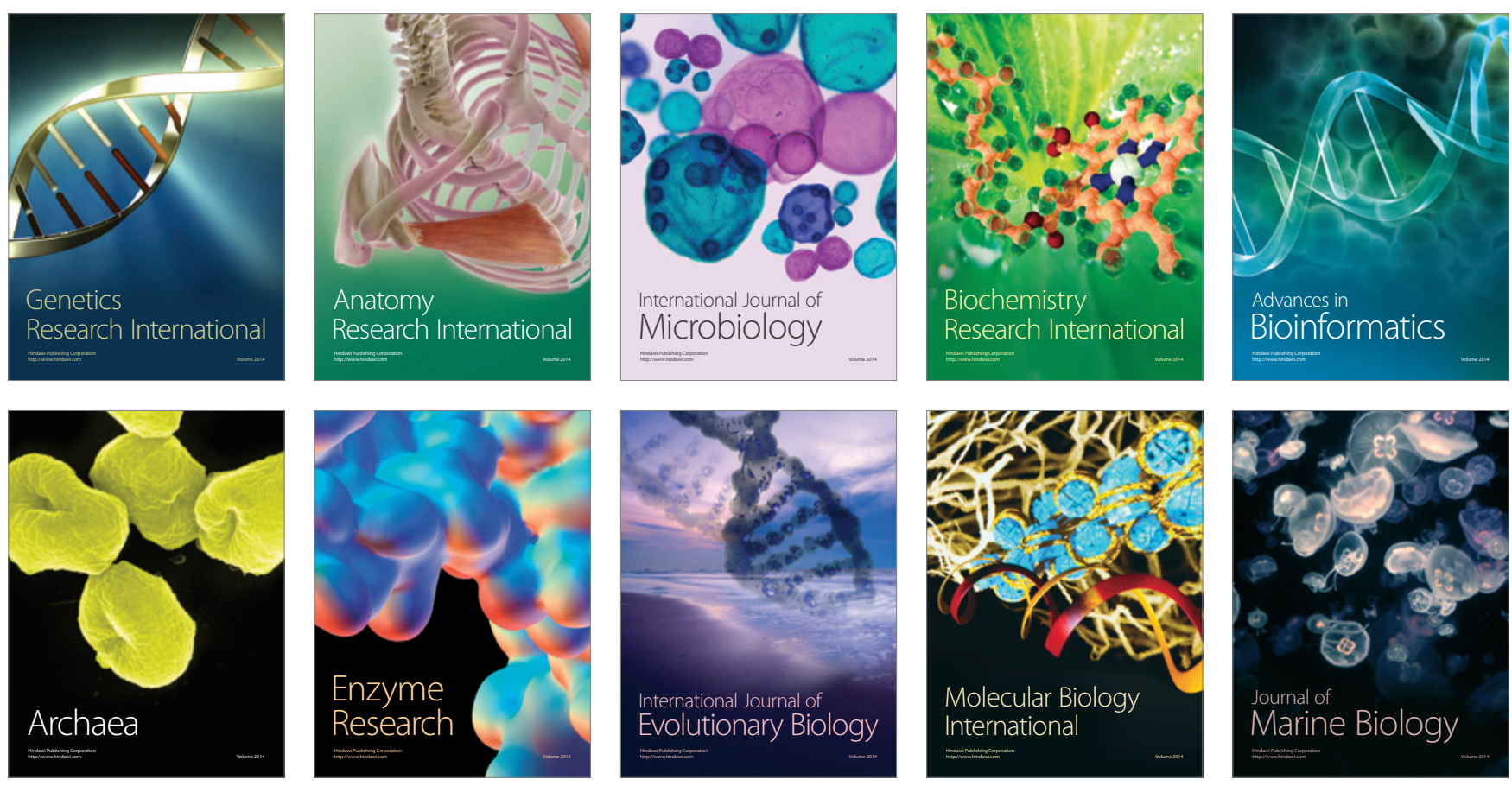